\title{
Basin evolution and shale tectonics on an obliquely convergent margin: the Bahia Basin, offshore Colombian Caribbean
}

\section{Pedro A. Galindo ${ }^{1 *}$ and Lidia Lonergan ${ }^{1}$}

${ }^{1}$ Department of Earth Science and Engineering, Imperial College London

Corresponding author; Pedro Galindo (pedro.galindo@ecopetrol.com.co)

* Current address: Ecopetrol S.A., Bogotá, Colombia

Key Points:

- In response to oblique convergence, strike-slip deformation occurs at the rear of the South Caribbean Deformed Belt and controls the evolution of the Bahia Basin

- Strike-slip deformation and sediment loading triggered the movement of overpressured shale, creating mud-withdrawal minibasins

- Strain-partitioning led to the break-up and lateral displacement of accretionary prisms formed along the margin, opening the space for depocenters

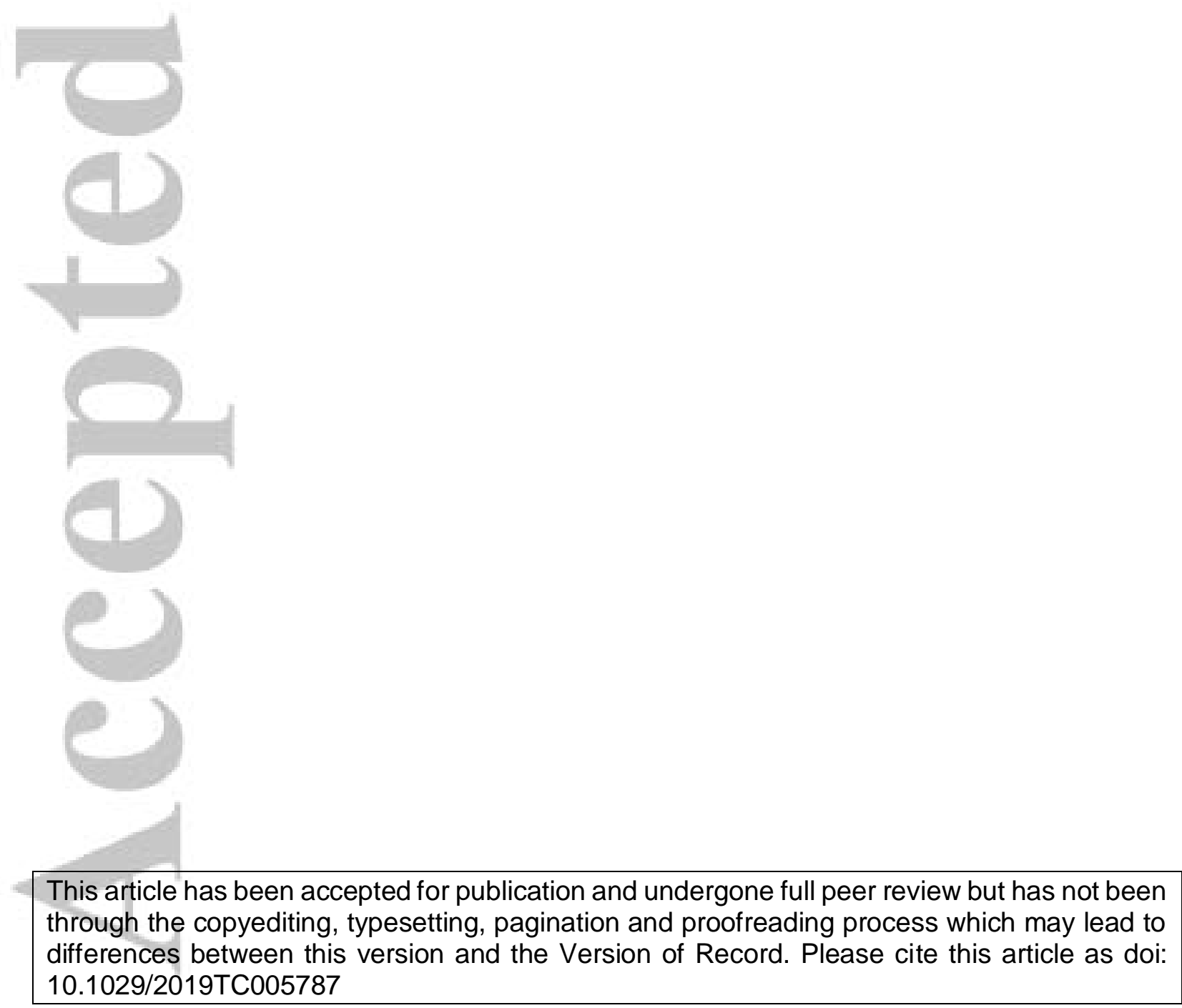




\begin{abstract}
Oblique convergent margins accumulate strike-slip deformation that controls basin formation and evolution. The Bahia Basin is located offshore, proximal to major strike-slip fault systems that affect northern Colombia. It lies behind the toe of the modern accretionary prism, where the Caribbean Plate is being subducted obliquely beneath South America. This is the first attempt using 3D seismic reflection data to interpret a complex strike-slip basin at the western end of the southern margin of the Caribbean Plate. Detailed 2D and 3D seismic mapping of regional unconformities and faults is used to describe the structural geometry, timing and evolution of extensional and strike-slip faults which controlled the formation of the basin. Analysis of the fault zones is coupled with a description of the seismicstratigraphic units observed within the Bahia Basin to reconstruct the spatial and temporal evolution of deformation, and to evaluate the influence of the pervasive shale tectonics observed in the area. The results, presented as a series of structural-paleogeographic maps, illustrate an initial stage of transtension that controlled the formation of shale-withdrawal minibasins from late Oligocene to late Miocene times. The continuous deformation and northward expulsion of the Santa Marta Massif resulted in transpression during Pliocene times, leading to basin inversion and ultimate closure of the basin. Basin evolution along the southern Caribbean oblique, convergent margin, shows the occurrence of a complex interaction between subduction and major-onshore strike-slip fault systems, and illustrates how strain-partitioning led to the break-up and lateral displacement of early accretionary prisms formed along the margin.
\end{abstract}

\title{
1. Introduction
}

A feature of oblique, convergent plate boundaries is strain partitioning between strikenormal motion at the frontal part of the forearc/accretionary prism near the subduction zone, and strike-parallel motion towards the rear of the accretionary wedge (e.g., Fitch, 1972; McCaffrey, 1992; Yu et al., 1993; among many others). How strain partitions at obliquely convergent margins has been discussed for a long time and addressed in a number of ways, including theoretical analyses of the mechanics (e.g., Beck, 1983; Haq \& Davis, 2010; Platt, 1993); analogue modelling (e.g., Casas-Sainz et al., 2001; Leever et al., 2011; McClay et al., 2004) and numerical modelling (e.g., Braun \& Beaumont, 1995). A key observation made by most authors is that the active strike-slip faults, which take up a significant proportion of the strike-parallel motion, occur some distance away from the active subduction zone towards the rear of the system, in the forearc region behind the accretionary prism. However, relatively fewer studies have addressed the geological evolution of basins and related deformation along these strike-slip systems. Examples of oblique convergent margins with strike-slip basins include the Sumatran margin (e.g., Martin et al., 2014), the Hikurangi margin (e.g., Barnes et al., 2005), the Aleutian margin (e.g., Ryan \& Scholl, 1989), the Ryukyu margin (e.g., Lallemand et al., 1999) and the Caribbean margin (e.g., Beardsley \& Avé Lallemant, 2007; Escalona \& Mann, 2011). Here we discuss the tectonic evolution of one such basin on the Colombian Caribbean margin, allowing us to investigate three interlinked problems pertinent to the development of strike-slip basins at obliquely converging margins: (1) the forearc kinematics of deformation in an oblique subduction setting, (2) the occurrence of transtension and transpression during the development of the pull-apart basin at the rear of the accretionary wedge, and (3) the interaction of regional strike-slip systems in the formation and evolution of local basins. We have the unique opportunity to study the basin using 3-D seismic reflection data with some well data, collected by the hydrocarbon industry, which allows novel insights into the tectonic evolution of this complex area. The new understanding that we develop for the southern, obliquely convergent margin of the Caribbean Plate in 
northern Colombia allows us to propose a new palaeogeographic reconstruction for the area from middle Eocene to Recent times.

The southwestern margin of the Caribbean is an area of complex deformation that includes the offshore Caribbean accretionary fold and thrust belt (South Caribbean Deformed Belt) and large strike-slip fault systems along the NW margin of South America (Figure 1). The South Caribbean Deformed Belt has deformed due to continuous oblique subduction in response to the eastern movement of the Caribbean Plate in relation to South America (e.g. Burke, 1988; Van der Hilst \& Mann, 1994; Kroehler et al., 2011; Pindell \& Kennan, 2009). The eastern movement of the Caribbean Plate results in strain partitioning and dextral strikeslip systems in the north and north-western margins of the South American Plate (F. A. Audemard \& Castilla, 2016; Escalona \& Mann, 2011). The most significant of these fault systems is the Oca-El Pilar Fault System, which strikes E-W along northern Colombia and Venezuela (Figure 1). The termination of the western end of the Oca Fault System is not clear; it is assumed to end in a series of splays close to the city of Santa Marta (F. A. Audemard, 1996). The Bahia Basin is located directly in front of the NW corner of the Santa Marta Massif, which is also the termination of the left-lateral, NW-SE trending Santa MartaBucaramanga Fault (Figure 1). Although the overall timing and structural styles of several basins along the South Caribbean margin have been previously analyzed (Escalona \& Mann, 2011; Paul Mann \& Escalona, 2011, and references therein), the structural styles and basin evolution at the western end of this margin has not been clearly understood and is generally only described at a regional scale.

This paper describes the structural geometry, timing and evolution of extensional and strike-slip faults that control the formation of the middle Eocene to Pleistocene Bahia Basin, using regional 2D and 3D seismic reflection data together with well data. The Bahia Basin is located ca. $60 \mathrm{~km}$ behind the South Caribbean Deformed Belt, offshore the NW corner of the Santa Marta Massif, and is the westernmost example of strike-slip deformation on the South Caribbean margin (Figure 1). The basin is bounded by three main faults, which we call A, C and $\mathrm{D}$, and is transected by a large NE-SW trending fault, which we name the Bahia Fault (i.e. Fault B), which bounds the main deeper depocenter to the SE of the basin (Figure 2). These four fault zones accommodated major extensional and strike-slip activity until late Miocene to early Pliocene times. The basin was inverted in Plio-Pleistocene times and the major structures were buried by sediments. Analysis of the fault zones is coupled with a description of the seismic-tectonic units observed within the Bahia Basin to reconstruct the spatial and temporal evolution of deformation, and to evaluate the influence of the pervasive mud volcanism observed in the area. The results are presented as a series of structuralpaleogeographic maps that illustrate the formation of the Bahia basin and show how strainpartitioning triggered the break-up and lateral displacement of early accretionary prisms formed along the margin. As suggested by recent thermochronological studies (Patiño et al., 2019; Piraquive et al., 2018; Villagómez et al., 2011), placing the results into a regional context indicates that there has been a complex interaction with major-onshore strike-slip fault systems, and that the uplift and NW movement of the Santa Marta Massif has likely induced the inversion of the basin in Pliocene times, with the ultimate closure of the basin.

\section{Regional geological setting}

Northern Colombia forms part of the SW margin of the oceanic Caribbean plate - a zone of deformation that is $600 \mathrm{~km}$ in strike length that has formed by oblique subduction of the Caribbean Plate since late Cretaceous times. The tectonics of northwest Colombia are further complicated by the subduction of the Nazca Plate beneath South America forming the Andes and the collision of the Panama Arc and the Choco Block in Miocene times (Duque- 
Caro, 1990; Egbue \& Kellogg, 2010; Pennington, 1981). Hence, the evolution of northern Colombia has been explained by a complex interaction of three tectonic plates bounded by major strike-slip and thrust systems (e.g., Cediel et al., 2003) (Figure 1).

Although the subduction of the Caribbean Plate below north-western South America has been long established (e.g., Burke et al., 1978; Dewey, 1972; Edgar et al., 1971; Ladd et al., 1984), the geometry and crustal structure of the Caribbean slab continues to be debated. Most recent studies using earthquake locations, seismic tomography and gravity modelling agree on the existence of a shallow slab $\left(<40^{\circ}\right)$ extending some $900 \mathrm{~km}$ along the length of Venezuela and northern Colombian margins of the South American plate (e.g., Van Benthem et al., 2013; Van der Hilst \& Mann, 1994; J. A. Mora et al., 2017; Sanchez-Rojas \& Palma, 2014; Syracuse et al., 2016; Taboada et al., 2000). The slab dips to the south under Venezuela and curves along strike to dip to the east in northwest Colombia (Van Benthem et al., 2013; Bernal-Olaya, Mann, \& Vargas, 2015; Bezada et al., 2010). Shallow, or flat slab subduction is attributed to the fact that the Caribbean plate is made of a dry, buoyant large igneous province of late Cretaceous age (e.g., Burke et al., 1978; Donnelly et al., 1973; Kerr et al., 1996, 1997; Syracuse et al., 2016).

As illustrated in Figure 1 the Bahia Basin is bounded to the north and west by the South Caribbean Deformed Belt, which includes both the Sinu and San Jacinto Fold Belts and the Neogene Magdalena Fan. The onshore Plato-San Jorge Basin of the Lower Magdalena Valley is located to the south and a tectonic domain known as the Maracaibo Block occurs to the south and east of the basin. These tectonic domains are described in the following section.

\subsection{South Caribbean Deformed Belt}

The South Caribbean Deformation Belt (SCDB) is the accretionary prism formed offshore Colombia and Venezuela, along the convergent margin between the Caribbean and South American Plates (e.g., Case et al., 1984; Ladd et al., 1984). The accretionary prism is currently forming in response to the ESE-directed subduction of the Caribbean Plate at a rate of $\sim 20 \mathrm{~mm} / \mathrm{yr}$ (Pérez et al., 2001; Symithe et al., 2015; Trenkamp et al., 2002; J. C. Weber et al., 2001). The sediments within the prism are interpreted as having been scrapped off the subducting crust, along with sediments deposited on top of the prism by prograding-deltaic systems coming from the continent (e.g., Magdalena River; Figure 1). The thick and buoyant Caribbean crust with its low angle of subduction, is thought to have prevented the formation of a typical bathymetric trench in front of the wedge (Kroehler et al., 2011; Mann \& Taira, 2004). Regionally, Müller et al. (1999) propose that NW-SE convergence between North and South America started in the early Eocene resulting in $200-400 \mathrm{~km}$ of shortening. Regionally, the SCDB is been considered to form a continuous fold and thrust belt from the Panama Arc in the west to northern Venezuela in the east (e.g., Van der Hilst \& Mann, 1994; Trenkamp et al., 2002). However, there is a gap, at least in its near surface continuity, in the area of the Magdalena Fan, which is used by Escalona and Mann (2011) to separate the Sinu and San Jacinto Fold Belts to the SW from the SCDB sensu stricto and Leeward Antilles to the NE. There are very few studies on the eastern side of the Magdalena Fan (i.e. western end of the SCDB sensu stricto) to and the few that exist focus on the fore-arc basins and the shelf area of the Nazareth and Jarara Basins (Escalante, 2006; I. Gomez, 2001; "Ranchería Basin" in Vence, 2008) and there are only a few published 2D seismic lines that image the accretionary prism.

The San Jacinto Fold Belt (SJFB) is a NNE-SSW trending imbricated thrust system with vergence to the WNW, and corresponds to the innermost, and oldest, accretionary wedge formed due to dextral-transpressional collision/accretion during the late Cretaceous to 
Eocene (Ruiz et al., 2000) or the Paleocene to Oligocene (Flinch, 2003). It is formed of late Cretaceous to Neogene sedimentary rocks deformed by high-angle faults with both reverse and right-lateral displacement. The basement composition beneath the wedge remains ambiguous; some models suggest it is oceanic crust (Flinch, 2003; Mora-Bohórquez et al., 2017), although studies using gravity modelling suggest an attenuated continental crust (Ceron-Abril, 2008) or a wedge of continental crust accreted during the initial stages of subduction (Mantilla-Pimiento, 2007). The Romeral Fault Zone forms the eastern boundary of the SJFB, which has been traditionally considered the main boundary between the South American continental crust and the accreted late Cretaceous to Paleocene oceanic crust of the Caribbean Plate (Bernal-Olaya, Mann, \& Escalona, 2015; e.g., Kennan \& Pindell, 2009; Kerr et al., 1996; Kerr, 1998) (Figure 1).

The Sinu Fold Belt (SFB) (Figure 1) is the outermost and on-going accretionary wedge interpreted as the result of the latest phase of subduction during late Miocene to Recent times (e.g., Duque-Caro, 1979; Ruiz et al., 2000). It is composed of west-verging imbricate thrusts forming tight anticlines with the development of piggy-back basins filled with a thick sequence of Plio-Pleistocene syntectonic sediments (e.g., Duque-Caro, 1979, 1984). The main detachment is interpreted to occur on a sequence of high-pressured shales of Oligocene age, which are also the source of the extensive mud volcanism observed along the Colombian coast (Duque-Caro, 1979, 1984; Galindo, 2016; Shepard et al., 1968; Vernette et al., 1992).

\subsection{Plato-San Jorge Basin}

The Plato-San Jorge Basin lies to the south of the study area between the Romeral Fault to the west and the Santa Marta-Bucaramanga Fault to the east (Figure 1). This basin is filled by a thick $(2-8 \mathrm{~km})$ sequence of paralic and marine sediments of late Eocene to Holocene age, and is compartmentalized by deep-rooted normal faults that affect the basement and sediments as young as late Miocene in age (Bernal-Olaya, Mann, \& Escalona, 2015; Cediel et al., 2003; Duque-Caro, 1979; Camilo Montes et al., 2010; Mora-Bohórquez et al., 2017). Inversion structures due to the reactivation of these faults during the Andean Orogeny have been observed close to the boundaries of the basin, specially associated with the Romeral Fault Zone, exposing strata as old as Miocene in age (Bernal-Olaya, Mann, \& Escalona, 2015; Camilo Montes et al., 2010).

\subsection{Maracaibo Block}

The triangular-shaped Maracaibo Block has been interpreted as an isolated tectonic block, separated from the Northern Andes terrane and the Guyana Shield (i.e. South American Plate) during Cenozoic times (Cediel et al., 2003; Paul Mann \& Burke, 1984; Pindell \& Kennan, 2009). It is bounded by the NE-SW trending Bocono Fault in the SE, the NW-SE trending Santa Marta-Bucaramanga Fault in the SW, and the Oca Fault in the north (Figure 1). Several studies suggest that the Maracaibo Block has been 'escaping' to the north-east in response to the complex collision of the Panama Arc with South America in western Colombia (F. A. Audemard \& Castilla, 2016; F. E. Audemard \& Audemard, 2002; Paul Mann \& Burke, 1984; Pindell et al., 1988; Pindell \& Kennan, 2009; Taboada et al., 2000 ) or the collision and subduction of the Carnegie Ridge since Pleistocene times (Egbue \& Kellogg, (2010). Pindell \& Kennan (2009) suggested that the tectonic escape accelerated during the last $10 \mathrm{Ma}$, although it might have started moving in late Oligocene to early Miocene times (Mauffret \& Leroy, 1997; Müller et al., 1999; Pindell et al., 1988). However, models by F. E. Audemard \& Audemard (2002) and F. A. Audemard (2009) have constrained the NE movement of the Maracaibo Block to the last $5 \mathrm{Ma}$, which is supported by field 
studies (Backé et al., 2006), and the presence of Quaternary pull-apart basins along the rightlateral Bocono Fault in the Merida Andes (Schubert, 1984). This fault accommodates much of the tectonic escape moving at a rate of $9-12 \mathrm{~mm} / \mathrm{yr}$ (Pérez et al., 2001; Symithe et al., 2015; Trenkamp et al., 2002). Overall, the movement of the Maracaibo Block in the northwestern corner of South America has been recorded by the uplift of the main mountain ranges in the northernmost section of the Andes: NE-SW trending Merida Andes and Perija Range (Leonardo Duerto et al., 2006; Kellogg, 1984; De Toni \& Kellogg, 1993), and the Santa Marta Massif in the north-western corner of the block (Patiño et al., 2019; Villagómez et al., 2011) (Figure 1).

The uplift of the Santa Marta Massif has been interpreted as the result of a complex interaction between both the subduction of the relatively buoyant Caribbean-oceanic-plateau ((Bernal-Olaya, Mann, \& Escalona, 2015); Ceron-Abril, 2008; Spikings \& Simpson, 2014), and the large-lateral displacements related to the relative northward escape of the Maracaibo Block. Detailed mapping of the Santa Marta Massif and neighboring basins (Colmenares et al., 2007; Piraquive et al., 2018; Tschanz et al., 1974) together with thermochronological studies (Patiño et al., 2019; Villagómez et al., 2011) suggest a three-staged episodic exhumation of the massif in (1) the Paleocene-Eocene with the uplift of the once-continuous Central Cordillera-Santa Marta Massif belt (Bayona et al., 2012; Agustín Cardona et al., 2010; Ceron-Abril, 2008; Camilo Montes et al., 2010); (2) the late Oligocene-Miocene related to the opening of the Lower Magdalena Basin, with the clockwise rotation of the Santa Marta Massif of $23^{\circ}$ to $30^{\circ}$ (Camilo Montes et al., 2010), accompanied by the simultaneous shortening in the Perija Range (e.g. Kellogg, 1984); and (3) the middle Miocene to Recent in response to the onset of shallow subduction of the Caribbean Plate .(Bernal-Olaya, Mann, \& Escalona, 2015), which also registered an uplift in the Perija Range and the Cesar-Rancheria Basin (Sanchez and Mann, 2015).

\subsubsection{Oca and Santa Marta-Bucaramanga Fault Systems}

The E-W trending Oca Fault separates the Santa Marta Massif to the south from the Guajira Peninsula in the north (Figure 1). This right-lateral fault is part of the Oca-El Pilar Fault System that extends ca. $650 \mathrm{~km}$ eastward from northern Colombia to western Venezuela. The estimation of the displacement along the Oca Fault has been a matter of debate and values between 65 and $125 \mathrm{~km}$ are the most commonly cited (Blanco et al., 2015; Kellogg, 1984; Camilo Montes et al., 2010; Pindell et al., 1998; Tschanz et al., 1974). Most authors postulate that the displacement has occurred since the Oligocene (Kellogg, 1984; Pindell et al., 1998), although rotation models of Camilo Montes et al. (2010) suggest movement may have started as early as in the late Eocene. Neotectonic studies by F. A. Audemard (1996) indicate that the Quaternary displacements rates are ca. $2 \mathrm{~mm} / \mathrm{yr}$.

The NNW-SSE trending Santa Marta-Bucaramanga Fault has a length of ca. $550 \mathrm{~km}$ (Figure 1). The left-lateral displacement of the fault has been estimated by different authors mainly from field observations, and ranges between 40 and $130 \mathrm{~km}$, with $110 \mathrm{~km}$ being the most accepted value (Campbell, 1965; Irving, 1975; Camilo Montes et al., 2010; Pindell et al., 1988, 1998; Toro, 1990; Tschanz et al., 1974). Several authors have proposed that the northward movement of the Maracaibo Block, along the Santa Marta-Bucaramanga Fault, began in the Miocene (Pindell et al., 1988, 1998). However, apatite fission track and provenance data in the Santander Massif (i.e. Bucaramanga segment) suggest activity since early Paleogene times (Ayala et al., 2012; Duddy et al., 2009). GPS studies indicate a current northward movement rate of $6 \mathrm{~mm} / \mathrm{yr}$ for the Santa Marta-Bucaramanga Fault consistent with ongoing tectonic escape of the Maracaibo Block (Trenkamp et al., 2002), although recent 
paleomagnetic studies along the Bucaramanga segment suggest a current rate of displacement at ca. $3 \mathrm{~mm} / \mathrm{yr}$ (Jiménez et al., 2015).

\section{Data and methods}

This study combines bathymetry data, 2D and 3D marine seismic reflection data, and well data provided by ECOPETROL S. A. The study area includes the western side of the Santa Marta Massif and the northern termination of the San Jacinto Fold Belt onshore, between the coastal cities of Santa Marta and Cartagena, and the Santa Marta Bay, the Magdalena Fan, and the northern part of the Sinu Fold Belt offshore, covering an area of ca. $100,000 \mathrm{~km}^{2}$ (Figure 1). The topography and bathymetry data are a regional merge of satellite data and high-resolution multi-beam bathymetry. The offshore bathymetric data have a resolution of $50 \mathrm{~m}$ while the onshore data are only $2 \mathrm{~km} \times 2 \mathrm{~km}$.

2D seismic reflection lines used in this study include data from six surveys acquired between 1975 and 1999. The data consist of 53 lines that collectively extend $\sim 3000 \mathrm{~km}$ in length and cover an approximate area of $18,000 \mathrm{~km}^{2}$ (Figure 1). All lines are in time (TWT) and present variable record lengths, all ranging between 7 and 10 seconds and sample rate of $4 \mathrm{~ms}$. Frequency content ranges between 20 and $60 \mathrm{~Hz}$. The 3D seismic volume, Bahia-3D, was acquired in 2003. The pre-stack, time-migrated (PSTM) seismic volume covers an approximate area of $1400 \mathrm{~km}^{2}$, with a spacing of $25 \mathrm{~m}$ between NE-SW trending lines and $12.5 \mathrm{~m}$ between the corresponding cross-lines. The volume has a record length of 7 seconds TWT (ca. $8 \mathrm{~km}$ ), with a sample rate of $4 \mathrm{~ms}$. The seismic volume has an average frequency content of $30 \mathrm{~Hz}$ which gives a maximum horizontal resolution of ca. $25 \mathrm{~m}$ and a vertical resolution of ca. $20 \mathrm{~m}$. Acquisition parameters are industry standard, with near zero phase and SEG normal polarity.

Three exploration wells are located in the study area (A-1, B-1 and C-1, Figure 1, inset maps in Figures 2-4). A-1 well was drilled in 2007, at a water depth of $535 \mathrm{~m}$. This borehole is located within the 3D seismic volume, and allowed us to assign late Oligocene to Holocene ages to the stratigraphy (Text S1 and Figure S1 in the supporting information). B-1 and C-1wells were drilled closer to the shoreline in 1979 and 1981, respectively. However, as the wells are located on the structural highs, the ages of the deeper strata within the local depocentres are not constrained.

Interpretation of the combined 2D-3D seismic reflection dataset was performed with Landmark's Openworks, Geoprobe and Decision Space software. The 3D seismic reflection data are of high quality, particularly in the shallowest section (ca. 0-4 s TWT). However, the active and extensive mud volcanism and the highly complex structural setting hinder the interpretation, especially in the deeper pre-Oligocene section. Multiple unconformities were identified in the data, and the more regionally continuous were picked as significant tectonostratigraphic surfaces (Figure 2). These surfaces were interpreted based on geometric relationships, truncated reflections, and contrasts between seismic facies. Time-structure maps of seismic surfaces and time-thickness maps (i.e. isochron maps) of seismic units between the unconformities were calculated to reveal structural and depositional trends. Furthermore, a variety of seismic attributes (e.g., similarity, coherency, spectral decomposition, edge-detect) were used to facilitate the interpretation of faults and mud volcanoes. 2D seismic data is of good to fair image quality particularly in the shallowest section (ca. 0-4 s TWT), but decreases considerably with depth. In addition, the presence of BSR's (Bottom Simulator Reflectors), seismic multiples, gas chimneys and pervasive mud volcanism hinder the interpretation in places. However, the grid of $2 \mathrm{D}$ data displays numerous line intersections that allow good cross-correlation. The integration of $2 \mathrm{D}$ lines 
with the 3D seismic survey enabled us to interpret faults and structural style beyond the limits of the 3D data.

\section{Structural setting of the Bahia Basin}

The NW-SE seismic line in Figure 2a illustrates the structural styles across the SCDB and the Bahia Basin. Five NW-verging thrusts form the front $45-50 \mathrm{~km}$ of the wedge and the Bahia Basin comprises the ca. $13 \mathrm{~km}$ thick and $20 \mathrm{~km}$ wide depocenter at the rear. Within the $\mathrm{SCDB}$, the geometry of anticlines and thrust faults varies through the belt. The frontal anticline (labelled 1 in Figure 2) is symmetrical, with a main thrust fault with vergence to the NW in the fore-limb (Figures 2 and, 3), and a backthrust with vergence to the SE in the back limb (Figure 2a). Towards the rear of the belt, the anticlines are asymmetric, the faults are steeper and detach deeper, presumably within the late Cretaceous to middle Eocene, and possibly reaching the top of the subducting oceanic crust (Figures 2 and 3 ).

Significant variations also occur along the strike of the belt. Although, the general trend of the structures in the SCDB is NE to SW, bathymetry data show that the frontal toe of the SCDB is convex in shape, with the main structures rotating to trend almost N-S as they approach the Magdalena Fan, as also noted by other authors (Breen, 1989; Cerón et al., 2007; Martinez et al., 2012; Restrepo-Correa \& Ojeda, 2010; Ruiz et al., 2000; Vernette et al., 1992). In addition, the belt seems to decrease in width from $50 \mathrm{~km}$ in the center, where at least five thrusts are present, to $45 \mathrm{~km}$ in the west, where four thrusts occur (Figure 2).

At the rear of the accretionary prism, seismic data shows the occurrence of several depocenters in the subsurface, that are not evident in the bathymetry data. The Bahia Basin displays an E-W elongated geometry in plan view with narrow, triangular shapes at both ends (inset map in Figure 2). A steep fault, A, with apparent extensional displacement defines the northwestern boundary of the basin. The Bahia Basin is transected by a fault (Bahia Fault) that exhibits early extensional deformation followed by inversion, and the landward margin of the basin is defined by another transtensional fault, $\mathrm{C}$ (Figures $\mathbf{2}$ and 3).

Within the study area three types of shale-tectonic features are found: 1) mud volcanoes; 2) thickening of the shale into the core of the anticlines and diapir formation in the fold and thrust belt; and 3) lateral movement and shale withdrawal associated with sediment loading in the Bahia Basin. A large number of mud volcanoes can be observed on the bathymetric and seismic data. The volcanoes are identified by pyramidal/conical structures of circular to elliptical-base shape, with a maximum diameter of $2 \mathrm{~km}$, a maximum flank slope of 30 degrees, and a maximum height of ca. $240 \mathrm{~m}$ above the seabed. A significant number of mud volcanoes are located close to, or immediately overlying, the steep faults behind the SCDB (i.e. thrust faults and Fault A - e.g., Figures 2 and 3) suggesting that the overpressured fluids that fed the mud volcanoes were released along these faults. Buried mud volcanoes that terminate within Miocene and Plio-Pleistocene sediments also occur indicating a long history of mud and fluid mobilization in the area (Figure 4a). The source for remobilized mud is the overpressured Oligocene-Miocene shales (e.g., Figure 4a).

In the SCDB, the Oligocene to early Miocene shale unit frequently thickens within the core of the anticlines creating diapiric-like structures (structures 3 and 4 in Figure 2a). In some cases, volcanoes can be observed to be sourced from the thickened shales along thrusts and extrude within younger stratigraphy or at the present-day sea floor. Within the Bahia Basin itself, mud volcanoes and shale diapirs are concentrated along fault zone A on the north-western basin margin, but some volcanoes are also found elsewhere in the basin as seen in Figure 4a for example. Finally, examples of shale movement, associated with rapid thickness changes in both the shale unit itself and the overlying younger strata, are also found 
within the dataset. Some of the geometries resemble salt-withdrawal structures found in salt provinces. An example of this is seen very clearly in Figure $\mathbf{4 b}$, within the Bahia Basin area where the thickening of Oligocene section towards the NW occurs in response to the development of a down-building minibasin towards the axis of the basin.

\section{Tectono-stratigraphy of the Bahia Basin}

Key unconformities, and seismic events present within the data were used to identify a series of tectono-stratigraphic units within the basin. Data from the A-1 well is used to constrain the ages of the sedimentary sequence (Figures $2 \mathrm{a}$ and $4 \mathrm{~b}$, and Text S1, Text S2 and Figure S1 in the supporting information). The four surfaces tied to the A-1 well are an intraPleistocene horizon (Figure 5a), the upper Miocene to lower Pliocene unconformity (UMLPU) (Figure 5b), the middle Miocene unconformity (MMU) (Figure 5c), and the upper Oligocene to lower Miocene unconformity (UOLMU) (Figure 5d). A sixth and deepest surface, below the well TD, is interpreted as the middle Eocene unconformity (MEU) (Figure 5e) because of its strong seismic response and the correlation with similar events observed in the NW corner of South America (e.g. Escalona \& Mann, 2011; J. A. Mora et al., 2017; Pindell \& Kennan, 2009; Sanchez \& Mann, 2015).

\subsection{Intra-Pleistocene horizon}

The intra-Pleistocene horizon is the deepest reflection that can be mapped continuously throughout the survey (Figure 4). The time-structure map of this surface (Figure 5a) is broadly similar in shape to the seabed, deepening from SW to NE and showing evidence of mud volcanism mainly in the north-west of the survey.

\subsection{Upper Miocene to lower Pliocene unconformity}

Below the intra-Pleistocene horizon, the next important surface that can be mapped relatively continuously through the area is the upper Miocene to lower Pliocene unconformity (UMLPU) (Figure 5b). This surface is tied to the top of the Miocene in the A-1 well (green horizon in Figures 3 and 4). In general, the UMLPU time-structure map (Figure 5b) shows a complex structural configuration with the presence of several highs and lows and a range in time between $1400 \mathrm{~ms}$ and $5000 \mathrm{~ms}$ TWT. Fault zones A and C are identified towards the north-western and southern margins of the basin, respectively. The Bahia Fault, through the center of the map, is the south-eastern boundary of two highs located in the middle of the area of study; further to the north the fault steps to the left and bounds a northern high (southern$\mathrm{SH}$, central-CH and northern highs-NH in Figure 5f). The main depocenter of the basin occurs to the SE of the Bahia Fault, and it is also bounded by highs to the south and to the east. These boundaries resemble those observed on the intra-Pleistocene map (cf. Figure 5a).

The deepest area of the broadly triangular-shaped depocenter is towards the east in front of Fault D. Towards the west, the basin shallows in a series of steps produced by NEdipping normal faults until it reaches Fault $\mathrm{C}$ as the main boundary (Figure 5b, f). The highs to the NW area of the Bahia Fault are the footwalls of early normal faults that are now partially inverted, and bound a deep basinal area to the south (Figure 4). Northwest of the fault, the UMLPU is relatively easy to follow because of the presence of onlap and toplap truncations of the reflections (Figure 4).

\subsection{Middle Miocene unconformity}

Below the UMLPU a local, angular unconformity is identified on seismic data (e.g., blue surface on Figures 3 and 4). Here sub-horizontal, parallel and continuous reflections 
above the middle Miocene surface overlie a synformal structure with sediments of lower to middle Miocene age. This synformal structure was drilled by the A-1 well and is in the same area of the southern high observed in the UMLPU time-structure map (cf. Figure 5b-c). Outside of this area, this surface is mapped following the base of the sub-horizontal upper Miocene sequence, the identification of onlap and toplap truncations, and the presence of a similar synformal structure observed in the hanging wall of the Bahia Fault (Figure 3c).

The middle Miocene unconformity (MMU) time-structure map (Figure 5c) shows a very similar geometry to the UMLPU. A main triangular depocenter is preserved on the south-eastern side (i.e. hanging-wall) of the Bahia Fault, bounded by high areas towards the east and south. On the north-western side of the fault (i.e. footwall), the southern, central and northern highs are preserved. However, towards the western side of the study area (Figure 5c), the MMU disappears as sediments below the unconformity have either been eroded by the UMLPU or were not deposited (Figure 4b).

\subsection{Upper Oligocene to lower Miocene unconformity (top of mobile shale)}

The bottom of the A-1 well reaches the top of the Oligocene, which defines the base of the synformal structure observed in seismic data (Figures 3c and $\mathbf{4 b}$ ). Below this event, dim and chaotic reflections characterize the Oligocene seismic unit. This type of seismic signature is interpreted as being overpressured shale, supported by the identification of mud volcanoes within the area of the 3D seismic survey, with a deep source, below the Miocene sequence (Figure 4a).

The main depocenter of the Bahia Basin to the SE of the Bahia Fault is evident on the upper Oligocene to lower Miocene unconformity (UOLMU) time-structure map (Figure 5d). The prominent highs in the east and south of the Bahia Basin are still very evident. The map also shows isolated highs related to the presence of mud volcanoes, and an extensive high towards the NW which is associated with the large number of mud volcanoes observed in this area. A main difference compared to previous maps is the absence of isolated highs on the footwall of the Bahia Fault.

\subsection{Middle Eocene Unconformity}

A deeper unconformity is also present in the dataset, beneath which the strata are folded indicating an earlier phase of folding and shortening (Figure 4a). The middle Eocene unconformity (MEU) (Figure 5e) is present in the central area of the survey, on the northwestern side of the Bahia Fault. Here a clear angular relationship is observed (AU in Figure 4a) between folded pre-middle Eocene strata and the overlying Oligocene to Miocene sequence. The most likely interpretation of this unconformity is that it records the Eocene deformation and uplift of the San Jacinto Fold Belt. Unfortunately, the angular unconformity is only clearly imaged in the central area of the survey so elsewhere the MEU is the base of the overlaying overpressured-shale sequence of Oligocene age. Thus, the middle Eocene unconformity is interpreted at the boundary between the dim and chaotic reflections of the Oligocene above, and the presence of strong and continuous reflections beneath. On the south-eastern side of the Bahia Fault the MEU is identified in the high areas to the south (Figure 2b) and east (Santa Marta Massif) (Figure 3c) that bound the main basinal area. In these high areas, the middle Eocene unconformity corresponds to a very strong event at the base of the Oligocene to Miocene sequence, where onlap geometries are also present. This strong reflectivity may respond to the presence of limestones that have been described onshore at the top of the Eocene sequence (Duque-Caro, 2006; Flinch, 2003; Guzmán, 2007; J. A. Mora et al., 2017; Rincón et al., 2007). 


\section{Geometry of the main Bahia Basin Faults}

\subsection{Faults A and A'}

Fault A, which is planar and steeply dipping $\left(70-90^{\circ}\right)$ to the southeast, trends NE-SW along the north-western boundary of the Bahia Basin, extending for ca. $70 \mathrm{~km}$. Another fault, A' which trends E-W to NW-SE, forms the northern boundary of the eastern extension of the basin. This fault is also steeply dipping and it is likely that it is a splay of Fault A, joining with the Oca Fault System (Figure 6). The geometry of Fault A on the seismic data and the alignment of mud volcanoes in places along the fault zone, suggest that it may be comprised of a series of linked segments (Figure 6). At depth in the subsurface, the thickening of the chaotic shale section hinders fault-plane interpretation. Thus, Fault A is defined by the normal displacement of the UMLPU, the thickening towards the south of the Plio-Pleistocene units within the Bahía Basin, and the normal offset of the dim and chaotic reflections that characterizes the overpressured-shale section of Oligocene age (Figures $\mathbf{2}$ and 3). At the western part of the fault, it has consistent extensional displacement from middle Eocene to lower Pliocene times (see time-structure maps in Figure 5), with a maximum vertical displacement of ca. $800 \mathrm{~ms}$ TWT at the UMLPU level (Figure 3a). Through the widest part of the Bahia Basin, Fault A exhibits a decrease in the dip angle as low as ca. $45^{\circ}$ with normal offset of ca. $400 \mathrm{~ms}$ TWT at the UMLPU. An anticline is present in the hanging-wall of the fault which is evidence of later inversion (Figure 3b). Fault A is interpreted to increase in dip with depth, and probably roots into the subduction zone, similar to other strike-slip faults within the Bahia Basin (Figure 3b). In the eastern-sector of the basin, Fault A' likewise has extensional displacements, up to ca. 1000 ms TWT (Figure 6).

\subsection{Bahia Fault}

The Bahia Fault is a linear, NE-SW trending fault that is ca. $50 \mathrm{~km}$ long in the 3D seismic area (Figure 5), and turns to trend E-W towards the eastern part of the basin (Figure 6). It compartmentalizes the broad Bahia Basin formed between Faults A and C, and timestructure maps show a consistent main depocenter on the south-eastern side of the fault (Figure 5b-e). Although the fault is covered by Plio-Pleistocene sediments, the fault plane is very well defined at the UMLPU. In map view (Figure 5b, f), the Bahia Fault is formed by three main left-stepping segments in an en-echelon geometry (i.e. Bs, southern; Bc, central; and $\mathrm{Bn}$, northern), forming two relay areas between $\mathrm{Bs}$ and $\mathrm{Bc}$, and between $\mathrm{Bc}$ and $\mathrm{Bn}$. These fault segments progressively amalgamate with depth, at MMU (Figure 5c, g) and UOLMU (Figure 5d, h), merging into a single fault plane at the MEU (Figure 5e, i). This geometry is consistent with a strike-slip fault with right-lateral displacement.

The southern segment (Bs) is interpreted as a splay of Fault $\mathrm{C}$, opening a triangularshaped depocenter with NE-verging normal faults connecting the two boundaries (i.e. faults $\mathrm{B}$ and $\mathrm{C}$; Figure 5f-i). This segment (Bs) has a consistent dip towards the NW consistent with a late stage of shortening and basin inversion during Pliocene times causing a rotation of the fault plane and the uplift of the north-western side of the fault (Figure $\mathbf{4 b}$ ). The relay area between $\mathrm{Bs}$ and $\mathrm{Bc}$ is characterized by the formation of a negative flower structure where the main displacement has been accumulated towards the SE (Figure 4a). Normal displacement increases along Bc and reaches a maximum vertical throw of ca. $1800 \mathrm{~ms}$ TWT (Figure 5b). Further to the NE, a second inversion structure is formed on the south-eastern side of the Fault $\mathrm{Bc}$ and the relay zone with segment $\mathrm{Bn}$. This may respond to the buttressing effect produced by the compression of the basin fill against the Bahia Fault (Figure 3b). 


\subsection{Fault $\mathrm{C}$}

Fault $\mathrm{C}$ is an $\mathrm{E}-\mathrm{W}$ trending fault zone located at the southern boundary of the Bahia Basin. The fault is composed by multiple fault segments that amalgamate into a main fault zone forming a stepped transition between the shelf to the south and the Bahia Basin towards the north, associated with a notable thickening of the lower Pliocene to Holocene section (Figure 5). Fault $\mathrm{C}$ is ca. $60 \mathrm{~km}$ long from the intersection with Fault $\mathrm{A}$ in the west to the truncation against Fault D towards the east; further east, the Oca Fault System is interpreted as the likely continuation of Fault C (Figure 6). As the basin widens and deepens from west to east, the normal offset at the UMLPU level increases from 800 (Figure 3a) to $3200 \mathrm{~ms}$ TWT (Figure 2b). The fault segments have a planar geometry, high dips $\left(>70^{\circ}\right)$, and while the southernmost segments have low displacement and do not affect the MEU, the northern ones affect the entire pre-upper Miocene sequence to the basement (Figure 2b).

The continuation of Fault $\mathrm{C}$ towards the east displays a complex intersection between the E-W Fault C and the N-S Fault D (Figure 3b-c). The occurrence of a normal fault dipping towards the basin in the hanging wall of Fault D, indicates the continuity of some segments of Fault C. This normal displacement affects pre-early Pliocene rocks, suggesting that Fault D off sets Fault $\mathrm{C}$ during a Plio-Pleistocene event of shortening. Hence, the continuation towards the east of Fault $C$ is clearly disrupted by Fault D. Sections to the NE of Fault D (Figure 6) show a trend of E-W normal faults, which may correspond to the easternmost continuation of Fault $\mathrm{C}$. Towards the east, the strike of the faults change to NWSE, in the direction of the coastline, suggesting that these faults may be part of the Oca Fault System (Figure 3c). Geomorphologic studies by Restrepo-Correa \& Ojeda (2010), also support the interpretation of high-angle normal faults as part of the horsetail termination of the Oca Fault controlling the formation of the deepwater "La Aguja" canyon.

\subsection{Fault D}

Fault D is a linear, north-south fault that is ca. $40 \mathrm{~km}$ long in the study area and may continue towards the south. In the south (Figure 2b), the planar fault exhibits a high angle $\operatorname{dip}\left(>80^{\circ}\right)$ towards the east, and is the boundary of a deep depocenter in which the C-1 well is located. This well encountered the top of an undifferentiated Miocene section between $384 \mathrm{~m}$ and $3737 \mathrm{~m}$ below sea level. Here, a normal displacement is interpreted along the fault; however, the presence of an anticline in the hangingwall indicates a later inversion event. Northwards, within the area of the 3D seismic volume, the dip of Fault D decreases and it appears to be a simple thrust. This thrust forms the eastern boundary of the Bahia Basin and coincides with large changes in thickness in the Plio-Pleistocene sequence, providing evidence for uplifting and shortening along Fault D during post-late Miocene times (Figure 3b).

From a regional perspective, Fault D occurs along strike of the left-lateral Santa Marta-Bucaramanga Fault. Figure 3c shows a regional 2D-3D seismic line crossing obliquely the Bahia Basin and extending towards the NE, in front of the northern extension of the Santa Marta Massif. Fault D can be clearly seen on the western side of the Santa Marta Massif dipping towards the east, while the Santa Marta-Bucaramanga Fault System is expressed as two high-angle planar faults dipping steeply to the west. Given the changes along strike of Fault D, and the evident history of extension and inversion, it is suggested that this fault forms a splay at the northern termination of the regional Santa Marta-Bucaramanga Fault System and strike-slip movement is responsible for the offset of the older Fault C. 


\section{Tectono-sedimentary interpretation of the Bahia Basin fill}

A series of time-thickness maps have been calculated from the mapped surfaces in order to reveal further structural and deposition trends during the formation of the basin fill (Figure 5j-n; see also Text $\mathbf{S 2}$ in the supporting information).

The deepest unit in the area is defined as Pre-middle Eocene although no well in the Colombian offshore has confirmed its presence. However, Paleocene and early Eocene sediments have been drilled in the adjacent Plato-San Jorge Basin and have also been described in the outcropping sections of the San Jacinto Fold Belt (e.g., Duque-Caro, 1979; Flinch, 2003; Guzmán, 2007; J. A. Mora et al., 2017). There, hemipelagic shales occur interbedded with turbiditic sandstones and conglomerates overlain by Eocene reefal

limestones. In the central area of the Bahia Basin, the pre-middle Eocene sequence is clearly visible as a folded section capped by an angular unconformity (Figure 4a). This deformation is interpreted as the offshore extension of the San Jacinto Fold Belt, which has a regional NESW trend along the NW Colombian shoreline but has not been described offshore.

The next unit of middle Eocene to late Oligocene is the shale-rich section that has been generally described as the source of the mud volcanism observed along the northwestern Colombian coast. This isochron map (Figure 5n) shows a rather thin unit $(<500 \mathrm{~ms}$ TWT) in the center of the Bahia Basin, with thicker areas towards the margins, particularly towards the NW, where most of the mud volcanism is observed. This would support a hypothesis of mobile shale being expelled to surrounding areas in response the subsequent loading of sediments in the Bahia Basin from Miocene to younger times.

In contrast to previous unit, the isochron map of the upper Oligocene to middle Miocene section (Figure 5m) shows an increase of thickness towards the basin axis, particularly in the north-western side of the Bahia Fault. This thickening is evidence of fault control in the evolution of the basin during early Miocene times. Furthermore, areas of high thickness (>1000 ms TWT) are localized depocenters (minibasins 1 to 4, MB1-4 in Figure 5m) where the underlying shale unit is thin; this supports the hypothesis of mobile shale during the initial stages of the Bahia Basin. An example can be seen in the localized minibasin drilled by the A-1 well (MB1 on Figure 5m, see also Figure 4b). In this minibasin, the maximum thickness is observed on the western side of the Bahia Fault and progressively decreases towards the west and NW; correspondingly, the Oligocene-shale unit thickens in the same direction (Figure 5n).

The upper Miocene section (Figure 5l) shows the initiation of significant sediment accumulation in the south of the basin, localized in the hanging-walls of the southern and central segments of the Bahia Fault. However, some depocenters are still preserved on the footwall (NW) of the fault. The minibasin in which the A-1 well is located (MB1) continues to increase its thickness. Minibasins 2 and 3 are amalgamated into one larger depocenter on the footwall of the central segment of the Bahia Fault (MB2-3), and minibasin 4 is preserved, albeit smaller, in the footwall of the northern segment (Figure 5l). Towards the south, the decrease in thickness suggests that the deposition is also partially controlled by movement on Fault $\mathrm{C}$, but there is no evidence of any activity on Fault $\mathrm{D}$ as yet.

Between the UMLPU and the intra-Pleistocene horizon there is a sedimentary sequence characterized by the presence of growth strata packages bounded by multiple local unconformities that in most cases are not continuous through the whole survey (e.g., Figure 4b). These growth strata packages are the evidence of active tectonic activity from late Miocene to Pleistocene times. The isochron map (Figure 5k) shows the expansion of the main depocenter in the south-eastern side of the Bahia Fault. This main basinal area deepens 
towards the east adjacent to Fault D, reaching thickness greater than $3000 \mathrm{~ms}$ TWT. The south-western extension of the basin continues growing between Fault $\mathrm{C}$ and the Bahia Fault, reaching thickness between 2000 and $2700 \mathrm{~ms}$ TWT. In the footwall of the Bahia Fault, previous depocenters are now accumulating less sediments ( $<1000 \mathrm{~ms}$ TWT) and coincide with the high areas observed in the UMLPU time-structure map ( $\mathrm{SH}, \mathrm{CH}$ and $\mathrm{NH}$ in Figure 5f).

The youngest isochron map, covering the Pleistocene to Recent (Figure 5j) shows a thick area towards the west, which is interpreted as the Recent deposition associated with the Magdalena Fan. A local depocenter aligned N-S in the eastern side of the basin may represent control of Fault D, while an isolated depocenter in the center of the basin may represent some ongoing control on deposition by movement on the Bahia Fault. Thinner section on the north-western side of the survey can be correlated to the large amount of mud volcanism observed in this area, which suggests activity along Fault A.

\section{Discussion}

\subsection{Evolution of the Bahia Basin}

A model of the evolution of the Bahia Basin based on the structural observations, and seismic mapping is presented as a series of 5 block diagrams in Figure 7. Prior to the middle Eocene, regional studies have proposed a continuous process of collision, subduction and accretion between the Caribbean Plate and the NW corner of South America. This process results in the formation of the SJFB (e.g., Flinch, 2003; J. A. Mora et al., 2017). This accretionary wedge is widely exposed along west and NW Colombia (Figure 1). The Bahia Basin is located offshore of the NE trending SJFB, and the identification of a prominent angular unconformity (MEU; Figures 4a and 5e) above folded strata suggest that SJFB continues into the study area and forms the basement of the Bahia Basin, as shown on Figure $7 a$.

During middle Eocene to late Oligocene times, the Bahia Basin was a forearc depocenter characterized by shale-rich terrigenous sediments derived from the collided Caribbean terranes (e.g., Escalona \& Mann, 2011) (Figure 7b). As a result of the oblique convergence strain, strike-slip systems started to form at the rear of the accretionary prism where thick shale-rich units were deposited. These dextral strike-slip systems may start as left-stepped en-echelon Riedel shears, as described by analogue models (e.g., Atmaoui et al., 2006; McClay et al., 2004); one evidence of this, is the northward stepping of the segments of the Bahia Fault (Figure 5b).

By late Oligocene to middle Miocene times the initial strike-slip displacement appears to have been localized on a shear zone between Bahia and A faults at the rear of the continuously active accretionary wedge. Sedimentation was focused within the Bahia Basin due to a combination of strike-slip displacement and shale movement, creating down-building mini-basins on the north-western side of the Bahia Fault (Figures 4b, 5m and 7c).

Regionally, the middle Miocene is characterized by the emplacement of the Choco block and initial collision of the Panama Arc in western Colombia (Duque-Caro, 1979, 1990; Camilo Montes et al., 2010; Camilo Montes, Cardona, et al., 2012). This collision and the continuous south-eastward shallow subduction of the Caribbean Plate result in the inversion and uplift of the northern Andes, including the Eastern Cordillera, and the formation of the proto-Magdalena river, events that provide large amounts of sediments to the Caribbean basins (e.g., Bernal-Olaya, Mann, \& Escalona, 2015; Escalona \& Mann, 2011; E. Gomez, Jordan, Allmendinger, \& Cardozo, 2005). In the Bahia Basin, deformation is partitioned 
along the Bahia Fault and Fault $\mathrm{C}$, with a subordinate Fault A. The main depocenter has shifted to the south-eastern side of the Bahia Fault. The middle to upper Miocene isochron map (Figure 5l) shows a sharp boundary on the southern margin of the Bahia Basin and the presence of oblique-stepped faults between faults $\mathrm{C}$ and the Bahia Fault indicating displacement along both faults. However, the basin is markedly asymmetric towards the north-western side, possibly indicating a larger strain partitioning on the Bahia Fault. On the other hand, isolated depocenters are still preserved on the north-western side of the Bahia Fault. This may indicate continued shale movement and related down-building of the minibasins in response to the rapid sedimentation of the Magdalena Fan (Figures $\mathbf{4 b}, \mathbf{5 l}$ and $\mathbf{7 d}$ ).

The latest stage of the basin evolution since early Pliocene times is complex and includes continuous extension and basin inversion (Figure 7e). Regionally, the NW corner of South America is affected by the final collision of the Panama Arc and the Carnegie Ridge, causing the tectonic escape of the Maracaibo Block along the Bocono and Santa MartaBucaramanga fault systems (e.g., F. A. Audemard \& Castilla, 2016; Egbue \& Kellogg, 2010; Taboada et al., 2000). Thus, the most important fault active during this time is Fault D on the eastern margin of the Bahia Basin, which is part of the Santa Marta- Bucaramanga fault system accommodating both the northward-movement and uplift of the Santa Marta Massif. The upper Miocene to intra-Pleistocene isochron map (Figure 5k) still shows a main depocenter on the south-eastern side of the Bahia Fault, but the thickest area is located towards the east close to Fault D. On the other side, the south-western corner of the basin continues growing between Fault $\mathrm{C}$ and the Bahia Fault along the oblique-stepped faults suggesting continuous movement along these faults (Figures 5f, $\mathbf{k}$ ).

\subsection{Role of the mobile shale in the evolution of the Bahia Basin}

Strike-slip deformation occurring at the rear of the SCDB is likely the main mechanism to explain the opening of the Bahia Basin (Galindo, 2016). However, the pervasive mud volcanism observed in the area, together with localized minibasins identified on isochron maps and a highly variable thickness of an overpressured-shale unit, suggest an important role of mud mobilization during the evolution of the Bahia Basin. Figure $\mathbf{8}$ is a schematic cross-sectional model which illustrates the formation of down-building, mudwithdrawal minibasins in the context of the strike-slip tectonics of the Bahia Basin. Although sediment loading leading to the formation of salt withdrawal minibasins is well known in salt provinces (e.g., Giles \& Rowan, 2012; Hudec et al., 2009; Sylvester et al., 2015), it is increasing being recognized in areas of mobile shale where similar basin geometries have been observed (Blanchard et al., 2019; Leo Duerto \& McClay, 2011; Dupuis et al., 2019; Ings \& Beaumont, 2010; Morley, 2003; Morley \& Guerin, 1996; Soto et al., 2010).

During pre-middle Eocene times (Figure 8a) the initial subduction process formed a younger accretionary prism (i.e. SJFB). The deep-water fold and thrust belt is covered by a thick sequence of pelagic shales during Oligocene to early Miocene times (Figure 8b). At early Miocene times (Figure 8c) the cumulative strike-slip deformation may have formed faults A and Bahia creating a pull-apart basin between these two faults. The Bahia Fault may have had a relative major control in the deposition causing the initial thickening of sediments in the hanging wall of the fault (i.e. north-western side). The load of sediments results in the rapid burial of the Oligocene shale section, preserving porosity and fluids within the shales. Then, the shales remained undercompacted and the fluids became overpressured, triggering the mud mobilization as ductile flow and producing the swelling of the shale section in the downdip direction (e.g., mud diapirs) and extrusion at the sea bottom (i.e. mud volcanoes). Hence, the geometry of the mud-withdrawal minibasin is controlled to the SE by the normal displacement along the segments of the Bahia Fault, possibly as a negative flower structure, 
and towards the NW by the swelling of the shale. The filling of the minibasin is characterized by multiple unconformities (e.g., Figures $\mathbf{3 c}$ and $\mathbf{4 b}$ ) that record the changes in the relationship between the rates of diapir rising, and the rate of deposition within the minibasin, similar to those observed in salt-withdrawal minibasins (e.g., Giles \& Rowan, 2012).

During late Miocene times the continuous deposition of sediments contributed to shale withdrawal and downbuilding of the minibasin (Figure 8d). However, the Bahia Basin has widened, bounded by faults $\mathrm{A}$ and $\mathrm{C}$, and the Bahia Fault corresponds to a cross-basinal fault that compartmentalizes the basin. As the Bahia Fault continues controlling the deposition, a new minibasin is formed on the south-eastern side of the fault. Hence, mobile shale continues feeding rising diapirs and mud volcanoes in the downdip direction, towards Fault A, but also feeds the intermediate section along the Bahia Fault, and towards Fault $\mathrm{C}$ in a lesser extent.

Finally, a significant change in the stress field took place during Plio-Pleistocene times (Figure 8e). During this final stage, the Bahia Fault is the locus of a compressional stress (i.e. transpression), forcing the development of a positive flower structure (popup) and resulting in the partial inversion of Miocene minibasins on the north-western side of the fault. The uplift along the Bahia Fault forms an anticline structure whose growth is recorded by Plio-Pleistocene syntectonic sedimentation (Galindo, 2016). Growth strata are characterized by thinning and onlap geometries towards the crest, while paired depocenters are formed towards the flanks of the structure. Downbuilding of depocenters might have been continuous during the initial stages of deposition, but as shale increases its depth, the increasing temperature and digenetic processes may have reduced the shale's ductility, thus reducing its mobility and stopping the diapir rising (Day-Stirrat et al., 2010). However, the remnant overpressure is continuously released through pipes connected from the buried shale to mud volcanoes at the sea bottom.

8.3. Regional evolution of the Bahia Basin and implications for the tectonics of the NW corner of South America

Our new tectonic model for the evolution of the Bahia Basin, provides further important observations that contribute to the understanding of the complex tectonic evolution of the Caribbean-South American margin, particularly in the offshore area between the Magdalena Fan and the Santa Marta Massif (Figure 1). In this section, we integrate our new results with regional tectonic data to describe the paleogeographic evolution of the Bahia Basin area, in the context of the NW corner of South America since middle Eocene times (Figure 9). We use the Caribbean tectonic model of Pindell \& Kennan (2009) as a framework; their reconstruction is the current and most widely accepted model for the evolution of the Caribbean Plate, and has been tested by kinematic (Bochman et al., 2014) and tomographic (Van Benthem et al., 2013) studies. Furthermore, we integrate data from previous paleogeographic reconstructions at either regional (Escalona \& Mann, 2011; Paul Mann et al., 2006; Pindell et al., 1998; Pindell \& Kennan, 2009) and local scales (Bayona et al., 2012; Bernal-Olaya, Mann, \& Escalona, 2015; A. Cardona et al., 2018; Agustín Cardona et al., 2014; Duque-Caro, 1979; Flinch, 2003; E. Gomez, Jordan, Allmendinger, \& Cardozo, 2005; J. A. Mora et al., 2017; Moreno-Sánchez \& Pardo-Trujillo, 2003; Reyes-Harker et al., 2000; Villamil, 1999).

\subsubsection{Pre-Middle Eocene}

During late Cretaceous to early Paleogene times, the front of the Caribbean Plate collided with the NW corner of South America (Burke, 1988; Kennan \& Pindell, 2009; Pindell \& Kennan, 2009). As the Caribbean Plate moved northwards, the shallow and oblique 
subduction of the Caribbean Plate resulted in the accretion of island-arc and oceanic-plateau fragments into the continental margin (A. Cardona et al., 2018; Kennan \& Pindell, 2009; Kroehler et al., 2011; Vallejo et al., 2006; Wright \& Wyld, 2011). This event is also recorded by the presence of middle to high pressure metamorphic complexes in the NW corner of the Santa Marta Massif and the Guajira Peninsula (Agustín Cardona et al., 2010; M. Weber et al., 2010).

During Eocene times the northward movement of the Caribbean Plate was halted due to the collision against the North American Plate, resulting in an eastward movement of the Caribbean Plate relative to South America which induced a more orthogonal subduction zone beneath South America (Müller et al., 1999; Pindell \& Kennan, 2009). This subduction formed a continuous N-S uplifted region which includes the Central Cordillera, the Santa Marta Massif, the Guajira Peninsula and Leeward Antilles, and is also represented by intrusive magmatism along the margin and intra-plate volcanism (Bayona et al., 2012; A. Cardona et al., 2018; Agustín Cardona et al., 2011, 2014; Zapata et al., 2014) (Figure 9a). Onshore regions were characterized by subaerial depocenters with fluvial environments, as part of the proto-Maracaibo Basin (Ayala et al., 2012; Escalona \& Mann, 2011; E. Gomez, Jordan, Allmendinger, \& Cardozo, 2005; E. Gomez, Jordan, Allmendinger, Hegarty, et al., 2005; Villamil, 1999). In the offshore (e.g., Bahia Basin area), the San Jacinto accretionary prism had been forming since Paleocene times in the fore-arc region, and incorporating shallow marine to deepwater sediments (Duque-Caro, 1979; Flinch, 2003; Guzmán, 2007; Rincón et al., 2007). In the Bahia Basin area, deformation assumed to be part of the San Jacinto accretionary prism has been identified beneath a middle Eocene-aged angular unconformity, which correlates with a major regional unconformity developed onshore in NW South America, referred to as the middle Eocene unconformity (Duque-Caro, 1984; E. Gomez, Jordan, Allmendinger, \& Cardozo, 2005; J. A. Mora et al., 2017; Pindell \& Kennan, 2009; Villamil, 1999). This regional unconformity is thought to represent the onset of ESEdirected subduction responsible for shortening and the uplift of the north-western corner of South America. However we note that Mora et al. (2017) describe two unconformities during Eocene times in the neighboring Lower Magdalena Basin (i.e. lower to middle Eocene and upper Eocene). In the Bahia Basin, given the absence of well data that penetrate to this depth, these two unconformities might be amalgamated and only one unconformity is interpreted as top of the pre-middle Eocene tectonostratigraphic unit (Figure 4a, and supporting information Text S2 and Figure S1).

\subsubsection{Late Eocene to Oligocene}

The rate of eastward movement of the Caribbean Plate relative to South America reached a maximum during early to middle Eocene times (i.e. $36 \mathrm{~mm} / \mathrm{y}$ ) and then decreased to $24 \mathrm{~mm} / \mathrm{y}$ in the late Eocene and $18 \mathrm{~mm} / \mathrm{y}$ in Oligocene times (Müller et al., 1999; Pindell $\&$ Kennan, 2009). This decrease in the relative eastward movement is explained by the difficulty of subducting the relatively thick Caribbean plateau, and is consistent with the end of the Eocene magmatic activity and the onset of a non-magmatic transpressive margin (Bayona et al., 2012; Agustín Cardona et al., 2014). Furthermore, as a result of the shallow subduction of the Caribbean Plate, shortening and uplift started in the Perija Range and the Eastern Cordillera, separating the Magdalena Valley from the Maracaibo Basin (Leonardo Duerto et al., 2006; Escalona \& Mann, 2011; E. Gomez, Jordan, Allmendinger, \& Cardozo, 2005; Gorney et al., 2007; Taboada et al., 2000). At the same time, there is evidence that the early magmatic margin broke up by strike-slip movement into a series of separated blocks, with concomitant vertical-axis block rotation and basin opening between the Leeward Antilles and the Guajira region in the north (Beardsley \& Avé Lallemant, 2007; Gorney et al., 
2007; Macellari, 1995), and between the Central Cordillera and the Santa Marta Massif to the south (E. Gomez, Jordan, Allmendinger, \& Cardozo, 2005; Camilo Montes et al., 2010;

Reyes-Harker et al., 2000). Hence, strike-slip deformation may have started at this time along the left-lateral Santa Marta-Bucaramanga Fault and the right-lateral Oca Fault (Blanco et al., 2015; Escalona \& Mann, 2011; Gorney et al., 2007; Kellogg, 1984). Different degrees of clockwise rotation have been previously proposed for the Santa Marta Massif (and its bounding faults), ranging between $12^{\circ}$ (E. Gomez, Jordan, Allmendinger, \& Cardozo, 2005) and a maximum of $30^{\circ}$ (Camilo Montes et al., 2010). Regional models however, prefer a static position through time and just suggest the possibility of a slight rotation (Escalona \& Mann, 2011; Pindell \& Kennan, 2009). The model presented here requires a moderate rotation of the Santa Marta Massif to facilitate the occurrence of strike-slip deformation in the NW corner of South America (Figure 9b).

Oblique subduction, which commenced in Paleogene times, generated dextral transpression with the SJFB forming perpendicular to the margin and right-lateral displacement occurring at the rear of the accretionary prism, perhaps along the Romeral Suture. As strain partitioning occurred across the SJFB, and the Caribbean Plate moved eastward relative to South America, the Oca and Cuisa faults started to accumulate rightlateral deformation, which contributed to the break-up and lateral displacement of the early Paleogene margin. A slight rotation of the Santa Marta Massif due to the partition of deformation, would mean that faults such as the Cuisa and Oca faults may have originally been oriented in a more NE-SW trend, allowing them to accommodate strike-slip displacement (see change in Figures 9a-b). As a result, pull-apart basins started to form along the margin since late Eocene times initially in the north (i.e. northern Guajira and Leeward Antilles) (Gorney et al., 2007; Macellari, 1995), followed by the pull-apart basin formed along the Cuisa Fault in Oligocene times (I. Gomez, 2001; Vence, 2008). This may suggest a diachroneity in basin formation from north to south (Figure 9b). Further south, the Bahia Basin started to open at the western end of the newly-formed Oca Fault, where rightlateral displacement started to segment the SJFB (Figure 9b). This suggests that the opening of the Bahia Basin is primarily driven by the subduction processes, where strain partitioning occurs at the back of the wedge.

\subsubsection{Late Oligocene to middle Miocene}

The relative eastward movement of the Caribbean Plate accelerated during late Oligocene times (Escalona \& Mann, 2011; Müller et al., 1999; Pindell \& Kennan, 2009). As a result, intensive accretion at the sedimentary wedge continued the uplift of the SJFB and may have started the growth of the Sinu accretionary prism (Flinch, 2003). An important uplift event is also documented in the Santa Marta Massif (30-20 Ma, Patiño et al., 2019) and the Perija Range (Kellogg \& Bonini, 1982; Camilo Montes et al., 2010), suggesting a regional phase of exhumation. This shortening and uplift is recorded in the NW corner of South America as another regionally-extensive unconformity of late Oligocene to early Miocene in age (Duque-Caro, 1979, 1984; Rincón et al., 2007), which is also registered in the Bahia Basin (e.g. A-1 well, Figure 4b). As the eastward movement continued, right-lateral deformation continued along the Oca and Cuisa faults, which continued to dissect the earlyPaleogene margin and allowed the continuous opening of transtensional basins in N and NW South America (Gorney et al., 2007; Macellari, 1995; Camilo Montes et al., 2010). Thus, the Bahia Basin opened in early Miocene times at the western end of the Oca Fault, as a pullapart basin between the dextral right-stepping Fault A and Bahia Fault (Figure 9c). Further east, a NW-SE trending fault connected Fault A with the Oca Fault and formed the eastern end of the basin (i.e. Fault A'). These NW-SE trending faults formed at the rear of 
accretionary prism to transfer the right-lateral displacement to the Cuisa and Oca faults, contributing to the break-up and lateral displacement along the margin and controlling the deposition of marine sequences in the offshore basins ("Baja Guajira" in Escalante, 2006; "Ranchería" in Vence, 2008) and estuary systems in the Palomino basin (Piraquive et al., 2018) (Figure 9c).

On the western side of the Santa Marta Massif, the on-going clockwise rotation formed a sinistral pull-apart basin between the left-lateral Santa Marta-Bucaramanga and Algarrobo Faults (Bernal-Olaya, Mann, \& Escalona, 2015; Mora-Bohórquez et al., 2017; i.e. Aracataca Basin in Piraquive et al., 2018; i.e. Ariguani/Arjona Depression in Reyes-Harker et al., 2000). 2D seismic and well data in the southernmost part of the Bahia Basin (i.e. C-1 well, Figure 2b) show a deep depocenter filled with Miocene sediments that continued towards the continent. These observations may suggest a possible connection between the Ariguani Depression and the Bahia Basin during Miocene times (Figure 9c). At this time, the depositional environment was dominated by fan-delta deposits (i.e. Aracataca Basin in Piraquive et al., 2018) and deepwater turbidites (claystones and siltstones in A-1 well). As initially proposed by Duque-Caro $(1979,1984)$, this rapid deposition of turbidites during early Miocene times overpressured the mud-rich units of Oligocene age, resulting in shale movement and active mud volcanism. This activity is also recorded by the formation of mudwithdrawal minibasins in the area of the Bahia Basin (Figure 8c).

\subsubsection{Middle Miocene to lower Pliocene}

During middle Miocene times an angular unconformity is recorded in offshore regions of N and NW South America, including the Falcon Basin and Leeward Antilles (Gorney et al., 2007; Macellari, 1995), the Guajira Peninsula (Moreno et al., 2015; Vence, 2008), the Bahia Basin (Figure 4), and the SFB (Duque-Caro, 1984; Flinch, 2003). This angular unconformity is attributed to the collision of the Panama Arc and the Carnegie Ridge with the continuing shallow subduction of the Caribbean Plate beneath South America (Duque-Caro, 1990; C. Montes et al., 2015; Camilo Montes, Bayona, et al., 2012). This collision is also responsible for major uplift of the Santa Marta Massif, Perija Range and the Merida Andes (Leonardo Duerto et al., 2006; Kellogg, 1984; Patiño et al., 2019; Taboada et al., 2000), and uplift of the Eastern Cordillera (e.g., Reyes-Harker et al., 2015). The uplift of the Eastern Cordillera and the increasing topography in the northern Andes led to the establishment of the proto-Magdalena drainage system, which started to drain towards the northwest between the Central Cordillera and the Santa Marta Massif. This drainage started the infilling of the Plato-San Jorge Basin with terrestrial to deltaic (shallow marine) deposits (Bernal-Olaya, Mann, \& Escalona, 2015; Flinch, 2003; E. Gomez, Jordan, Allmendinger, \& Cardozo, 2005; E. Gomez, Jordan, Allmendinger, Hegarty, et al., 2005; Guzmán, 2007). Recent studies using seismic data interpret the northernmost extension of these deposits (i.e. the Magdalena Fan), as basin-floor fans of middle Miocene in age (Martinez et al., 2012) (Figure 9d).

This initial deposition of the Magdalena Fan in its current position (i.e. within a gap in the SCDB, Figure 1) has been interpreted as the infilling of a transfer zone between the SFB and the SCDB (Martinez et al., 2012; Ruiz et al., 2000). However, this interpretation suggests the occurrence of a WNW-ESE trending fault (i.e. Canoas Fault in Ruiz et al., 2000) as the northern termination of the SFB and the locus of this right-lateral transfer zone. However, further studies have not shown any structural evidence to support the occurrence of this fault, nor does it explain how this displacement is transferred towards the east (Flinch et al., 2003; Romero, 2009). More recently, studies using high quality bathymetry data (Romero, 2009) have found a NE-SW trending escarpment parallel to the shoreline in the area immediately 
inboard of main Magdalena Fan (dashed line on Figure 1). To the SW the escarpment aligns with the trend of the SFB-frontal thrust and continues towards the NE into the Bahia Basin, and hence it is interpreted as a fault zone (i.e. Galerazamba Fault on Figures 1 and 9d). In the Bahia Basin, this fault would appear to split along Faults A and C. Seismic lines in the Galerazamba area do not show a clear image to support the occurrence of this fault, but data from B-1 well suggests the relative shallow location of pre-Miocene strata supporting its location in a structural high, which can be interpreted as the footwall of a north-dipping transtensional fault (Figure 3a). On the other hand, seismic data in the Bahia Basin show similar fault geometries for the $\mathrm{C}$ and Oca Faults, which suggest that they are part of the same fault system. Hence, as most of the eastern movement of the Caribbean Plate is partitioned along the right-lateral Oca Fault System, we propose that the western end of this fault (i.e. Galerazamba and C Faults) is responsible for the separation and lateral displacement of both the older and current accretionary prisms (SJFB and SFB, respectively).

In summary, during middle to late Miocene times the Galerazamba Fault is responsible for the offset and separation of the SJFB and the active Sinu accretionary prism, providing the accommodation space for the early deposits of the Magdalena Fan. To the NE, the right-lateral deformation is transferred along faults A (i.e. Galerazamba Fault) and C (i.e. Oca Fault), which resulted in the continuous opening of the triangular-shaped Bahia Basin (Figure 9d). Within the basin, the cross-basinal Bahia Fault controlled the formation of depocenters at both sides of the fault, and the deposition of turbidites (related to the protoMagdalena River) continued the development of down-building minibasins (Figure 8d). The rapid deposition of the sediments coming off the rising cordilleras, and fed into the Caribbean by the Magdalena River system, loaded these sediments and triggered the mud volcanism along Fault A (Figures 7d and 8d).

\subsubsection{Plio-Pleistocene}

During late Miocene to early Pliocene times, a regionally-extensive unconformity is present along the margin of NW South America (Duque-Caro, 1984, 2006; Rincón et al., 2007), which correlates with an accelerated uplift in the northern Andes (e.g. Merida Andes, Leonardo Duerto et al., 2006; Eastern Cordillera, A. Mora et al., 2013). This peak in the Andean orogeny resulted from the onset of the current tectonic plate setting, where the Caribbean Plate is moving eastwards relative to South America at a rate of $\sim 20 \mathrm{~mm} / \mathrm{yr}$ (Symithe et al., 2015; Trenkamp et al., 2002; J. C. Weber et al., 2001) (Figure 9e). The Nazca Plate (Egbue \& Kellogg, 2010; Pennington, 1981) is subducting towards the east below NW South America at a rate of $60 \mathrm{~mm} / \mathrm{yr}$ (Trenkamp et al., 2002). The Panama Block is also moving eastwards ( $30 \mathrm{~mm} / \mathrm{yr}$; Trenkamp et al., 2002), suggesting a partial coupling of these tectonic blocks (Pindell \& Kennan, 2009). This eastward-directed compression from the Pacific not only has been proposed as the trigger for the last Andean uplift, but is also responsible for the north-eastward tectonic escape of the Maracaibo Block (Egbue \& Kellogg, 2010; Paul Mann \& Burke, 1984; Pindell et al., 1998; Taboada et al., 2000). This tectonic escape is mainly occurring along the south-eastern boundary of the Maracaibo Block, along the Bocono Fault (Merida Andes) at a rate of 9-12 mm/yr (Pérez et al., 2001; Symithe et al., 2015; Trenkamp et al., 2002). The block is also moving on the south-western border along the Santa Marta-Bucaramanga Fault at $6 \mathrm{~mm} / \mathrm{yr}$ (Trenkamp et al., 2002) or <3 $\mathrm{mm} / \mathrm{yr}$ (Jiménez et al., 2015; Symithe et al., 2015), and on the northern border along the Oca Fault at $<3$ mm/yr (F. A. Audemard, 1996; F. A. Audemard \& Castilla, 2016; Symithe et al., 2015). Further to the east, the eastward movement of the Caribbean Plate has been transferred to the El Pilar Fault in northern Venezuela where the rate of displacement reaches $20 \mathrm{~mm} / \mathrm{yr}$ (Jouanne et al., 2011; Reinoza et al., 2015; Symithe et al., 2015). Thus, the tectonic escape of 
the northern Andean block, and particularly the Maracaibo Block, transfers most of the rightlateral displacement to the Bocono Fault, and reduces significantly the slip rate along the Oca Fault from $\sim 20 \mathrm{~mm} / \mathrm{yr}$ to $<3 \mathrm{~mm} / \mathrm{yr}$.

Some studies have discussed the recent history of the Magdalena Fan and proposed a north-eastward movement of the river mouth, migrating from the Galerazamba area to its current position next to Barranquilla (Cadena, 2012; Kolla \& Buffler, 1984; Martinez et al., 2012; Molinares et al., 2012). This movement occurred in response to the uplift of the northeasternmost-onshore extension of the SJFB (Figure 1). Furthermore, the uplift of these hills occurred very recently, as Pleistocene carbonates outcrop along the Galerazamba area, and these could not have been deposited in a delta environment (Romero, 2009). Then, during Pliocene times the Magdalena Fan was deposited in the Galerazamba gap within the SCDB (i.e. SFB) as right-lateral deformation was transferred along the Galerazamba to the Oca Fault, producing the bending of the SCDB towards the continental shelf (Figure 9e). Finally, during Pleistocene times, the latest uplift of the SJFB onshore correlates with the bending and uplift of the SCDB offshore, which gives it its current shape (Figures 1 and 9e).

In the Bahia Basin, the most obvious effect of the northward movement of the Maracaibo Block is the change of the basin's shape, from a wide ENE-WSW elongated basin (i.e. Figure 9d) to a triangular basin with the eastern part squeezed in an E-W trend (Figure 9e). Within the basin, the expression of this tectonic escape is recorded by the growth of inversion-related structures during Plio-Pleistocene times (Galindo, 2016). Furthermore, this northern movement along the left-lateral Santa Marta-Bucaramanga Fault is divided in a horsetail-style along different fault segments reflected in the shape of the current Santa Marta Bay shore-line (Figure 1). One of these faults might correlate with the northernmost part of the Algarrobo Fault, as part of the Santa Marta-Bucaramanga Fault System. South of the Bahia Basin, the pull-apart basins formed in this left-lateral shear are inverted in response to the Maracaibo Block's tectonic escape. The offshore interpretation of 2D and 3D seismic data, identify Fault D as one of the faults that accumulate the displacement. Here, Fault D intersects the E-W trending Fault C, producing either the segmentation or the locking of the fault and triggering the jump of the right-lateral displacement towards a northern branch of the Oca Fault (Fault C, Figure 6). Assuming that Fault $C$ has been offset, and the eastern branch displaced northward by the indentation of the Santa Marta Massif, the current distance between the two parts of the fault is $\sim 30 \mathrm{~km}$, which suggests a left-lateral displacement of 6 $\mathrm{mm} / \mathrm{yr}$ for Fault D during the last $\sim 5 \mathrm{Ma}$ (Figure 9e). This slip-rate equals the value estimated by Trenkamp et al. (2002), but is double that the maximum rate expected from kinematic models (Symithe et al., 2015) and measured along the Bucaramanga Fault (i.e. 3 $\mathrm{mm} / \mathrm{yr}$, Jiménez et al., 2015). However, it is important to highlight that assuming a clockwise-rotation model of the Santa Marta Massif, the left-lateral escape would occur at the same time with the rotation and not just as a final stage. In addition, it is expected that the displacement must decrease towards the end of the fault given that 3D seismic data confirms the termination of the Santa Marta-Bucaramanga Fault.

\section{Conclusions}

1. The Bahia Basin is a forearc strike-slip basin formed at the rear of the SCDB and in front of the north-western corner of the Santa Marta Massif. This strike-slip zone formed in response to the ESE-directed, oblique subduction of the Caribbean Plate, where partitioning of the deformation occurs creating frontal thrusts parallel to the subduction front and strike-slip faults at the rear of the compressional zone. Then, the Bahia Basin formed at the intersection of two right-lateral, strike-slip faults: Fault A and Fault C, which correspond to the regional Galerazamba-Oca Fault System that accommodated the 
strain partitioning. A third fault is identified in the eastern boundary of the basin, Fault D, which corresponds to the northernmost section of the left-lateral Santa Marta-

Bucaramanga Fault System. Thus, seismic interpretation in the area of the Bahia Basin identifies the offshore continuation of the Santa Massif's bounding faults: a younger Santa Marta-Bucaramanga Fault, which cuts a paleo-Oca Fault.

2. The transtensional stage (late Oligocene to late Miocene) occurs within the northernmost section of the Colombian-Paleogene accretionary prism (i.e. SJFB), and is manifest as a pull-apart basin formation between faults $\mathrm{A}$ and $\mathrm{C}$ with a broad triangular shape. The Bahia Fault crosses the basin in a NE-SW trend, parallel to Fault A, and creates a shear zone of ca. $15 \mathrm{~km}$ wide. Hence, faults A, C and Bahia, are considered the manifestation of the continuous oblique subduction of the Caribbean Plate beneath the NW corner of South America. Strain is partitioned along these faults, opening a wide pull-apart basin with shifting depositional axes.

3. Rapid sedimentation of turbidites was localized in the early-forming Bahia Basin during Miocene times. The strike-slip deformation and the sediment loading triggered the movement of overpressured shale underneath, creating down-building minibasins initially on the north-western side of the Bahia Fault and then shifting to the south-eastern side. Some of the geometries identified on seismic data resemble salt-withdrawal structures found in salt provinces. This process may have started the pervasive mud volcanism observed in the area.

4. In the Pliocene to Holocene transpression dominated the deformation in the Bahia Basin. This could be attributed to continued deformation in a strike-slip setting, but is more likely to be related to the northward expulsion of the Santa Marta Massive, which led to a significant change in shape of the basin. A triangular part in the west is offset from a narrower E-W trending part to the east. Although oblique convergence is ongoing on the subducting plate, deformation in the upper plate appears to control deformation in the basin at this stage.

5. The strain-partitioning triggered the break-up and lateral displacement of accretionary prisms formed along the margin (i.e. SJFB, and SFB-SCDB), opening the space for the deposition of the Magdalena Fan and the local rotation trend of the SCDB towards the continental shelf on the eastern side of the Magdalena Fan. The larger scale arcuate shape of the SCDB across northern South America has formed as a response to the northeastward expulsion of the Maracaibo Block, in response to the continuous eastwarddirected collision of the Carnegie Ridge, the Nazca Plate and the Panama Block.

\section{Acknowledgments}

We thank the 'Departamento Administrativo de Ciencia, Tecnología e Innovación' (COLCIENCIAS) and their "Francisco José de Caldas" Scholarship Programme, and Imperial College London for funding for this research. ECOPETROL S. A. and Petrobras are acknowledged for providing the seismic and well data used for this research, and for the permission to publish these results. This study is part of the $\mathrm{PhD}$ project completed by $\mathrm{P}$. Galindo at Imperial College, and all models and interpretations are independent from the ideas of ECOPETROL S. A. Halliburton Software and Services, is acknowledged for providing the Landmark software used to interpret the seismic data under a university software grant. We thank D.J. Sanderson, R. Graham and J. Pindell for helpful discussions. Associate Editor Sean Long, A. Cardona and an anonymous reviewer provided helpful and constructive reviews. 


\section{References}

Atmaoui, N., Kukowski, N., Stöckhert, B., \& König, D. (2006). Initiation and development of pull-apart basins with Riedel shear mechanism: insights from scaled clay experiments. International Journal of Earth Sciences, 95(2), 225-238. https://doi.org/10.1007/s00531-005-0030-1

Audemard, F. A. (1996). Paleoseismicity studies on the Oca-Ancón fault system, northwestern Venezuela. Tectonophysics, 259(1), 67-80.

Audemard, F. A. (2009). Key issues on the post-Mesozoic Southern Caribbean Plate boundary. Geological Society, London, Special Publications, 328(1), 569-586. https://doi.org/10.1144/SP328.23

Audemard, F. A., \& Castilla, R. (2016). Present-day stress tensors along the southern Caribbean plate boundary zone from inversion of focal mechanism solutions: A successful trial. Journal of South American Earth Sciences, 71, 309-319. https://doi.org/10.1016/j.jsames.2016.06.005

Audemard, F. E., \& Audemard, F. A. (2002). Structure of the Mérida Andes, Venezuela: relations with the South America-Caribbean geodynamic interaction. Tectonophysics, 345(1-4), 1-26. https://doi.org/10.1016/S0040-1951(01)00218-9

Ayala, R. C., Bayona, G., Cardona, A., Ojeda, C., Montenegro, O. C., Montes, C., et al. (2012). The paleogene synorogenic succession in the northwestern Maracaibo block: Tracking intraplate uplifts and changes in sediment delivery systems. Journal of South American Earth Sciences, 39, 93-111. https://doi.org/10.1016/j.jsames.2012.04.005

Backé, G., Dhont, D., \& Hervouët, Y. (2006). Spatial and temporal relationships between compression, strike-slip and extension in the Central Venezuelan Andes: Clues for PlioQuaternary tectonic escape. Tectonophysics, 425, 25-53. https://doi.org/10.1016/j.tecto.2006.06.005

Barnes, P. M., Sutherland, R., \& Delteil, J. (2005). Strike-slip structure and sedimentary basins of the southern Alpine Fault, Fiordland, New Zealand. Bulletin of the Geological Society of America, 117(3), 411-435. https://doi.org/10.1130/B25458.1

Bayona, G., Cardona, A., Jaramillo, C., Mora, A., Montes, C., Valencia, V., et al. (2012). Early Paleogene magmatism in the northern Andes: Insights on the effects of Oceanic Plateau-continent convergence. Earth and Planetary Science Letters, 331-332, 97-111. https://doi.org/10.1016/j.epsl.2012.03.015

Beardsley, A. G., \& Avé Lallemant, H. G. (2007). Oblique collision and accretion of the Netherlands Leeward Antilles to South America. Tectonics, 26(2), 1-16. https://doi.org/10.1029/2006TC002028

Beck, J. M. E. (1983). On the mechanics of tectonic transport in zones of oblique subduction. Tectonophysics, 93, 1-11.

Van Benthem, S., Govers, R., Spakman, W., \& Wortel, R. (2013). Tectonic evolution and mantle structure of the Caribbean. Journal of Geophysical Research: Solid Earth, 118(6), 3019-3036. https://doi.org/10.1002/jgrb.50235

Berggren, W. A., Kent, D. V., Swisher, C. C., \& Aubry, M.-P. (1995). A Revised Cenzoic Geochronology and Chronostratigraphy. In Geochronology Time Scales and Global Stratigraphic Correlation (pp. 129-212). SEPM (Society for Sedimentary Geology), Special Publication 54.

Bernal-Olaya, R., Mann, P., \& Escalona, A. (2015). Cenozoic Tectonostratigraphic Evolution of the Lower Magdalena Basin, Colombia: An Example of an Under- to Overfilled Forearc Basin. In Claudio Bartolini \& P. Mann (Eds.), Memoir 108: Petroleum Geology and Potential of the Colombian Caribbean Margin (pp. 345-398). AAPG. https://doi.org/10.1306/13531943M1083645

Bernal-Olaya, R., Mann, P., \& Vargas, C. A. (2015). Earthquake, Tomographic, Seismic 
Reflection, and Gravity Evidence for a Shallowly Dipping Subduction Zone beneath the Caribbean Margin of Northwestern Colombia. In Claudio Bartolini \& P. Mann (Eds.), Memoir 108: Petroleum Geology and Potential of the Colombian Caribbean Margin (pp. 247-270). AAPG. https://doi.org/10.1306/13531939M1083642

Bezada, M. J., Levander, A., \& Schmandt, B. (2010). Subduction in the southern Caribbean: Images from finite-frequency $\mathrm{P}$ wave tomography. Journal of Geophysical Research: Solid Earth, 115(12), 1-19. https://doi.org/10.1029/2010JB007682

Blanchard, S., Matheson, E. J., Fielding, C. R., Best, J. L., Bryk, A. B., Howell, K., et al. (2019). Early burial mud diapirism and its impact on stratigraphic architecture in the Carboniferous of the Shannon Basin, County Clare, Ireland. Sedimentology, 66, 329361. https://doi.org//10.1111/sed.12492

Blanco, J. M., Mann, P., \& Nguyen, L. (2015). Location of the Suture Zone Separating the Great Arc of the Caribbean from Continental Crust of Northwestern South America Inferred from Regional Gravity and Magnetic Data. In Claudio Bartolini \& P. Mann (Eds.), Memoir 108: Petroleum Geology and Potential of the Colombian Caribbean Margin (pp. 161-178). AAPG. https://doi.org/10.1306/13531935M1083641

Bochman, L., Van Hinsbergen, D., Torsvik, T. H., Spakman, W., Pindell, J. L., Boschman, L. M., et al. (2014). Kinematic reconstruction of the Caribbean region since the Early Jurassic. Earth Science Reviews, 16, 6829.

https://doi.org/10.1016/j.earscirev.2014.08.007

Braun, J., \& Beaumont, C. (1995). Three-dimensional numerical experiments of strain partitioning at oblique plate boundaries: implications for contrasting tectonic styles in the southern Coast Ranges, California, and central South Island, New Zealand. Journal of Geophysical Research, 100(B9), 18,18-59,74. https://doi.org/10.1029/95JB01683

Breen, N. A. (1989). Structural effect of Magdalena fan deposition on the northern Colombia convergent margin. Geology, 17(1), 34-37. https://doi.org/10.1130/00917613(1989)017<0034:SEOMFD>2.3.CO;2

Burke, K. (1988). Tectonic Evolution of the Caribbean. Annual Review of Earth and Planetary Sciences, 16(1), 201-230. https://doi.org/10.1146/annurev.ea.16.050188.001221

Burke, K., Fox, P. J., \& Şengör, a. M. C. (1978). Buoyant ocean floor and the evolution of the Caribbean. Journal of Geophysical Research, 83(B8), 3949. https://doi.org/10.1029/JB083iB08p03949

Cadena, A. F. (2012). Middle Miocene - Holocene stratigraphic evolution of the Magdalena submarine fan: implications for deepwater architectural elements distribution in a tectonically active basin, offshore Colombia. University of Oklahoma, MSc Thesis.

Cadena, A. F., \& Slatt, R. M. (2013). Seismic and sequence stratigraphic interpretation of the area of influence of the Magdalena submarine fan, offshore northern Colombia. Interpretation, 1(1), SA53-SA74. https://doi.org/10.1190/INT-2013-0028.1

Campbell, C. J. (1965). The Santa Marta wrench fault of Colombia and its regional setting. In Fourth Caribbean Geological Conference (pp. 274-261). Trinidad.

Cardona, A., León, S., Jaramillo, J. S., Montes, C., Valencia, V., Vanegas, J., et al. (2018). The Paleogene arcs of the northern Andes of Colombia and Panama: Insights on plate kinematic implications from new and existing geochemical, geochronological and isotopic data. Tectonophysics, 749(October), 88-103.

https://doi.org/10.1016/j.tecto.2018.10.032

Cardona, Agustín, Valencia, V., Bustamante, C., García-Casco, A., Ojeda, G., Ruiz, J., et al. (2010). Tectonomagmatic setting and provenance of the Santa Marta Schists, northern Colombia: Insights on the growth and approach of Cretaceous Caribbean oceanic terranes to the South American continent. Journal of South American Earth Sciences, 
29(4), 784-804. https://doi.org/10.1016/j.jsames.2009.08.012

Cardona, Agustín, Valencia, V. A., Bayona, G., Duque, J., Ducea, M., Gehrels, G., et al. (2011). Early-subduction-related orogeny in the northern Andes: Turonian to Eocene magmatic and provenance record in the Santa Marta Massif and Rancheria Basin, northern Colombia. Terra Nova, 23(1), 26-34. https://doi.org/10.1111/j.13653121.2010.00979.x

Cardona, Agustín, Weber, M., Valencia, V., Bustamante, C., Montes, C., Cordani, U., \& Muñoz, C. M. (2014). Geochronology and geochemistry of the Parashi granitoid, NE Colombia: Tectonic implication of short-lived Early Eocene plutonism along the SE Caribbean margin. Journal of South American Earth Sciences, 50, 75-92. https://doi.org/10.1016/j.jsames.2013.12.006

Casas-Sainz, A. M., Gapais, D., Nalpas, T., Besnard, K., \& Román-Berdiel, T. (2001). Analogue models of transpressive systems. Journal of Structural Geology, 23(5), 733 743. https://doi.org/10.1016/S0191-8141(00)00153-X

Case, J. E., Holcombe, T. L., \& Martin, R. G. (1984). Map of geologic provinces in the Caribbean region. In W. E. Bonini, R. B. Hargraves, \& R. Shagam (Eds.), The Caribbean-South American Plate Boundary and Regional Tectonics (Vol. 162, pp. 130). Geological Society of America Memoirs 162. https://doi.org/10.1130/MEM162-p1

Cediel, F., Shaw, R. P., \& Cáceres, C. (2003). Tectonic Assembly of the Northern Andean Block. In C. Bartolini, T. Buffler, \& J. Blickwede (Eds.), AAPG Memoir 79: The Circum-Gulf of Mexico and the Caribbean: Hydrocarbon habitats, basin formation, and plate tectonics (pp. 815-848). Tulsa, OK: American Association of Petroleum Geologists.

Ceron-Abril, J. F. (2008). Crustal structure of the Colombian Caribbean Basin and margins. PhD Thesis. University of South Carolina, PhD Thesis.

Cerón, J. F., Kellogg, J. N., \& Ojeda, G. Y. (2007). Basement configuration of the northwestern South America - Caribbean margin from recent geophysical data. Ciencia, Tecnología y Futuro, 3, 25-49.

Colmenares, F., Mesa, A. M., Roncancio, J., Arciniegas, E., Pedraza, P., Cardona, A., et al. (2007). Geología de las planchas 11, 12, 13, 14, 18, 19, 20, 21, 25, 26,27, 33, 34 y 40. Proyecto: "Evolución geohistórica de la Sierra Nevada de Santa Marta." IngeominasInvemar-Ecopetrol-ICP-Geosearch Ltda. Bogotá, Colombia: Ingeominas-InvemarEcopetrol-ICP-Geosearch Ltda.

Cuartas, C., Jaramillo, C., \& Martínez, J. I. (2006). Quantitative biostratigraphic model for the tertiary of the lower Magdalena Basin, Colombian Caribbean. Ciencia, Tecnología y Futuro, 3(2), 7-28.

Day-Stirrat, R. J., McDonnell, A., \& Wood, L. J. (2010). Diagenetic and Seismic Concerns Associated with Interpretation of Deeply Buried 'Mobile Shales.' In L. J. Wood (Ed.), AAPG Memoir 93: Shale tectonics (pp. 5-28). Tulsa, OK, USA.: American Association of Petroleum Geologists. https://doi.org/10.1306/13231306M93730

Dewey, J. (1972). Seismicity and tectonics of western Venezuela. Bulletin of the Seismological Society of America, 62(6), 1711-1751. Retrieved from http://bssaonline.org/cgi/content/abstract/62/6/1711

Donnelly, T. W., Melson, W., Kay, R., \& Rogers, J. (1973). Basalts and dolerites of late Cretaceous age from the central Caribbean. In T. Edgar, A. Kaneps, \& J. Herring (Eds.), Initial reports of the Deep Sea Drilling Project. Volume $X V$.

Duddy, I. R., Parra Mantilla, P., Mora Hernández, C. A., \& Pimentel Trujillo, C. A. (2009). AFTA apatite fission track analysis constraints on the Mesozoic to Quaternary thermal and tectonic evolution of the Middle Magdalena Basin and Santander Massif , Eastern. In X Simposio Bolivariano Exploración Petrolera en Cuencas Subandinas (p. 14). 
Cartagena, Colombia: Asociación Colombiana de Geólogos y Geofísicos del Petróleo (ACGGP).

Duarte, L. M., Rizzi, J. A., Toledo, M. A., Reistroffer, J., Buitrago, J., Avella, E., et al. (2006). Estratigrafía y Controles Sedimentarios de la Cuenca Costa Afuera en el Caribe Colombiano. In IX Simposio Bolivariano - Exploración Petrolera en las Cuencas Subandinas (p. 11). Cartagena, Colombia: Asociación Colombiana de Geólogos y Geofísicos del Petróleo (ACGGP).

Duarte, L. M., Esteves, C. A., Zalán, P. V., Antolinez, H., \& Mosquera, J. C. (2009). Nuevos Conceptos para el Modelo Tectono - Estratigrafico de las Cuencas Sedimentarias en el Occidente del Caribe Colombiano. In X Simposio Bolivariano - Exploración Petrolera en las Cuencas Subandinas (p. 11). Cartagena, Colombia: Asociación Colombiana de Geólogos y Geofísicos del Petróleo (ACGGP).

Duerto, Leo, \& McClay, K. (2011). Role of the shale tectonics on the evolution of the Eastern Venezuelan Cenozoic thrust and fold belt. Marine and Petroleum Geology, 28(1), 81108. https://doi.org/10.1016/j.marpetgeo.2009.11.005

Duerto, Leonardo, Escalona, A., \& Mann, P. (2006). Deep structure of the Mérida Andes and Sierra de Perijá mountain fronts, Maracaibo Basin, Venezuela. AAPG Bulletin, 90(4), 505-528. https://doi.org/10.1306/10080505033

Dupuis, M., Imbert, P., Odonne, F., \& Vendeville, B. (2019). Mud volcanism by repeated roof collapse: 3D architecture and evolution of a mud volcano cluster offshore Nigeria. Marine and Petroleum Geology. https://doi.org/https://doi.org/10.1016/j.marpetgeo.2019.07.033

Duque-Caro, H. (1979). Major structural elements and evolution of northwestern Colombia. In J. S. Watkins, L. Montadert, \& P. Wood (Eds.), AAPG Memoir 29: Geological and Geophysical Investigations of Continental Margins (pp. 329-351). Tulsa, OK: American Association of Petroleum Geologists.

Duque-Caro, H. (1984). Structural style, diapirism, and accretioanry episodes of the Sinú-San Jacinto terrane, southwestern Caribbean borderland. In W. E. Bonini, R. B. Hargraves, \& R. Shagam (Eds.), The Caribbean-South American Plate Boundary and Regional Tectonics (pp. 303-316). Geological Society of America Memoirs 162.

Duque-Caro, H. (1990). Neogene stratigraphy, paleoceanography and paleobiogeography in northwest South America and the evolution of the Panama seaway. Palaeogeography, Palaeoclimatology, Palaeoecology, 77(3-4), 203-234. https://doi.org/10.1016/00310182(90)90178-A

Duque-Caro, H. (2001). Análisis Bioestratigráficos de pozos en las cuencas de costa afuera del Cinturón de Sinú, de Plato y de muestras varias en la costa NW Colombiana. Duque Caro \& CIA. LTDA. Ecopetrol Internal Report. Bogotá, Colombia: Duque Caro \& CIA. LTDA. Ecopetrol Internal Report.

Duque-Caro, H. (2006). COMENTARIO A : "Quantitative biostratigraphic model for the Tertiary of the Lower Magdalena Basin, Colombian Caribbean.” Ciencia, Tecnología y Futuro, 3(2), 183-196.

Duque-Caro, H., Guzmán, G., \& Hernández, R. (1996). Geología de la Plancha 38 Carmen de Bolívar. Memoria explicativa. Ingeominas. Bogotá, Colombia: Ingeominas.

Edgar, T., Ewing, J. I., \& Hennion, J. (1971). Seismic Refraction and Reflection in Caribbean Sea. AAPG Bulletin, 55(6), 833-870.

Egbue, O., \& Kellogg, J. N. (2010). Pleistocene to Present North Andean “escape.” Tectonophysics, 489(1-4), 248-257. https://doi.org/10.1016/j.tecto.2010.04.021

Escalante, C. E. (2006). Seismic Stratigraphy of the Tayrona Depression-Offshore Baja Guajira Basin, Colombia. In IX Simposio Bolivariano - Exploración Petrolera en las Cuencas Subandinas. Cartagena, Colombia: Asociación Colombiana de Geólogos y 
Geofísicos del Petróleo (ACGGP).

Escalona, A., \& Mann, P. (2006). An overview of the petroleum system of Maracaibo Basin. AAPG Bulletin, 90(4), 657-678. https://doi.org/10.1306/10140505038

Escalona, A., \& Mann, P. (2011). Tectonics, basin subsidence mechanisms, and paleogeography of the Caribbean-South American plate boundary zone. Marine and Petroleum Geology, 28(1), 8-39. https://doi.org/10.1016/j.marpetgeo.2010.01.016

Fitch, T. J. (1972). Plate convergence, transcurrent faults, and internal deformation adjacent to Southeast Asia and the western Pacific. Journal of Geophysical Research, 77(23), 4432-4460. https://doi.org/10.1029/JB077i023p04432

Flinch, J. F. (2003). Structural evolution of the Sinu-Lower Magdalena area (Northern Colombia). In C. Bartolini, R. T. Buffler, \& J. Blickwede (Eds.), AAPG Memoir 79: The Circum-Gulf of Mexico and the Caribbean: Hydrocarbon habitats, basin formation, and plate tectonics (pp. 776-796). Tulsa, OK: American Association of Petroleum Geologists.

Flinch, J. F., Amaral, J., Doulcet, A., Mouly, B., Osorio, C., \& Pince, J. M. (2003a). OnshoreOffshore Structure of the Northern Colombia Accretionary Complex. In AAPG International Conference (p. 5). Barcelona, Spain: American Association of Petroleum Geologists (AAPG).

Flinch, J. F., Amaral, J., Doulcet, A., Mouly, B., Osorio, C., \& Pince, J. M. (2003b). Structure of the Offshore Sinu Accretionary Wedge. Northern Colombia. In VIII Simposio Bolivariano - Exploración Petrolera en las Cuencas Subandinas (pp. 76-83). Cartagena, Colombia: Asociación Colombiana de Geólogos y Geofísicos del Petróleo.

Galindo, P. (2016). Transtension and transpression in an oblique subduction setting: Evolution of the Bahia Basin, Colombian Caribbean margin. Imperial College London, PhD Thesis. https://doi.org/https://spiral.imperial.ac.uk:8443/handle/10044/1/31408

Giles, K. A., \& Rowan, M. G. (2012). Concepts in halokinetic-sequence deformation and stratigraphy. Geological Society, London, Special Publications, 363(1), 7-31. https://doi.org/10.1144/SP363.2

Gomez, E., Jordan, T. E., Allmendinger, R. W., Hegarty, K., Kelley, S., \& Heizler, M. (2003). Controls on architecture of the Late Cretaceous to Cenozoic southern Middle Magdalena Valley Basin, Colombia. Geological Society of America Bulletin, 115(2), 131-147.

Gomez, E., Jordan, T. E., Allmendinger, R. W., \& Cardozo, N. (2005). Development of the Colombian foreland-basin system as a consequence of diachronous exhumation of the northern Andes. Geological Society of America Bulletin, 117(9), 1272. https://doi.org/10.1130/B25456.1

Gomez, E., Jordan, T. E., Allmendinger, R. W., Hegarty, K., \& Kelley, S. (2005). Syntectonic Cenozoic sedimentation in the northern middle Magdalena Valley Basin of Colombia and implications for exhumation of the Northern Andes. Geological Society of America Bulletin, 117(5), 547. https://doi.org/10.1130/B25454.1

Gomez, I. (2001). Structural style and evolution of the Cuisa fault system, Guajira, Colombia. University of Houston, MSc Thesis.

Gorney, D., Escalona, A., Mann, P., Magnani, M. B., Levander, A., Christeson, G., et al. (2007). Chronology of Cenozoic tectonic events in western Venezuela and the Leeward Antilles based on integration of offshore seismic reflection data and on-land geology. AAPG Bulletin, 91(5), 653-684. https://doi.org/10.1306/11280606002

Guzmán, G. (2007). Stratigraphy and Sedimentary Environment and Implications in the Plato Basin and the San Jacinto Belt Northwestern Colombia. Université de Liège. Université de Liège.

Haq, S. S. B., \& Davis, D. M. (2010). Mechanics of fore-arc slivers: Insights from simple 
analog models. Tectonics, 29(5), n/a-n/a. https://doi.org/10.1029/2009TC002583

Van der Hilst, R. P., \& Mann, P. (1994). Tectonic implications of tomographic images of subducted lithosphere beneath northwestern South America. Geology, 22(5), 451. https://doi.org/10.1130/0091-7613(1994)022<0451:TIOTIO>2.3.CO;2

Hudec, M. R., Jackson, M. P. A., \& Schultz-Ela, D. D. (2009). The paradox of minibasin subsidence into salt: Clues to the evolution of crustal basins. Geological Society of America Bulletin, 121(1-2), 201-221. https://doi.org/10.1130/B26275.1

Ings, S. J., \& Beaumont, C. (2010). Continental margin shale tectonics: preliminary results from coupled fluid-mechanical models of large-scale delta instability. Journal of the Geological Society, 167(3), 571-582. https://doi.org/10.1144/0016-76492009-052

Irving, E. M. (1975). Structural evolution of the Northernmost Andes, Colombia. Geological Survey Professional Paper 846. Washington, D. C.: Geological Survey Professional Paper 846. https://doi.org/10.1017/S0016756800050780

Jiménez, G., Speranza, F., Faccena, C., Bayona, G., \& Mora, A. (2015). Magnetic stratigraphy of the Bucaramanga alluvial fan: Evidence for $a \leq 3 \mathrm{~mm} / \mathrm{yr}$ slip rate for the Bucaramanga-Santa Marta Fault, Colombia. Journal of South American Earth Sciences, 57, 12-22. https://doi.org/10.1016/j.jsames.2014.11.001

Jouanne, F., Audemard, F. a., Beck, C., Van Welden, A., Ollarves, R., \& Reinoza, C. (2011). Present-day deformation along the El Pilar Fault in eastern Venezuela: Evidence of creep along a major transform boundary. Journal of Geodynamics, 51(5), 398-410. https://doi.org/10.1016/j.jog.2010.11.003

Kellogg, J. N. (1984). Cenozoic tectonic history of the Sierra de Perijá, Venezuela-Colombia, and adjacent basins. In W. E. Bonini, R. B. Hargraves, \& R. Shagam (Eds.), The Caribbean-South American Plate Boundary and Regional Tectonics (Vol. 162, pp. 239262). Geological Society of America Memoirs 162. https://doi.org/10.1130/MEM162p239

Kellogg, J. N., \& Bonini, W. E. (1982). Subduction of the Caribbean Plate and basement uplifts in the overriding South American Plate. Tectonics, 1(3), 251-276.

Kennan, L., \& Pindell, J. L. (2009). Dextral shear, terrane accretion and basin formation in the Northern Andes: best explained by interaction with a Pacific-derived Caribbean Plate? Geological Society, London, Special Publications, 328(1), 487-531. https://doi.org/10.1144/SP328.20

Kerr, A. C. (1998). Oceanic plateau formation: a cause of mass extinction and black shale deposition around the Cenomanian-Turonian boundary? Journal of the Geological Society, 155(4), 619-626. https://doi.org/10.1144/gsjgs.155.4.0619

Kerr, A. C., Tarney, J., Marriner, G. F., Nivia, A., Klaver, G. T., \& Saunders, A. D. (1996). The geochemistry and tectonic setting of late Cretaceous Caribbean and Colombian volcanism. Journal of South American Earth Sciences, 9(1-2), 111-120. https://doi.org/10.1016/0895-9811(96)00031-4

Kerr, A. C., Tarney, J., Marriner, G. F., Nivia, A., \& Saunders, A. D. (1997). The CaribbeanColombian cretaceous igneous province: The internal anatomy of an oceanic plateau. In Large Igneous Provinces: Continental, Oceanic, and Planetary Flood Volcanism (pp. 123-144). American Geophysical Union. https://doi.org/10.1029/GM100p0123

Kolla, V., \& Buffler, R. T. (1984). Morphologic, Acoustic, and Sedimentologic Characteristics of the Magdalena Fan. Geo-Marine Letters, 3(2-4), 85-91. https://doi.org/10.1007/BF02462452

Kroehler, M. E., Mann, P., Escalona, A., \& Christeson, G. L. (2011). Late CretaceousMiocene diachronous onset of back thrusting along the South Caribbean deformed belt and its importance for understanding processes of arc collision and crustal growth. Tectonics, 30(6), 31. https://doi.org/10.1029/2011TC002918 
Ladd, J. W., Truchan, M., Talwani, M., Stoffa, P. L., Buhl, P., Houtz, R., et al. (1984). Seismic reflection profiles across the southern margin of the Caribbean. In W. E. Bonini, R. B. Hargraves, \& R. Shagam (Eds.), The Caribbean-South American Plate Boundary and Regional Tectonics (Vol. 162, pp. 153-159). Geological Society of America Memoirs 162. https://doi.org/10.1130/MEM162-p153

Lallemand, S., Liu, C., Dominguez, S., Schnürle, P., \& Malavieille, J. (1999). Trench-parallel stretching and folding of forearc basins and lateral migration of the accretionary wedge in the southern Ryukyus: A case of strain partition caused by oblique convergence. Tectonics, 18(2), 231-247. https://doi.org/10.1029/1998TC900011

Leever, K. A., Gabrielsen, R. H., Sokoutis, D., \& Willingshofer, E. (2011). The effect of convergence angle on the kinematic evolution of strain partitioning in transpressional brittle wedges: Insight from analog modeling and high-resolution digital image analysis. Tectonics, 30(2). https://doi.org/10.1029/2010TC002823

Macellari, C. E. (1995). Cenozoic sedimentation and tectonics of the southwestern Caribbean pull-apart basin, Venezuela and Colombia. AAPG Bulletin, 62, 757-780.

Mann, Paul, \& Burke, K. (1984). Neotectonics of the Caribbean. Reviews of Geophysics and Space Physics, 22(4), 309-362. https://doi.org/10.1029/RG022i004p00309

Mann, Paul, \& Escalona, A. (2011). Introduction to the special issue of Marine and Petroleum Geology: Tectonics, basinal framework, and petroleum systems of eastern Venezuela, the Leeward Antilles, Trinidad and Tobago, and offshore areas. Marine and Petroleum Geology, 28(1), 4-7. https://doi.org/10.1016/j.marpetgeo.2010.07.003

Mann, Paul, Escalona, A., \& Castillo, M. V. (2006). Regional geologic and tectonic setting of the Maracaibo supergiant basin, western Venezuela. AAPG Bulletin, 90(4), 445-477. https://doi.org/10.1306/10110505031

Mantilla-Pimiento, A. M. (2007). Crustal Structure of the Southwestern Colombian Caribbean Margin. Friedrich-Schiller-Universität Jena, PhD Thesis.

Martin, K. M., Gulick, S. P. S., Austin, J. A., Berglar, K., Franke, D., \& Udrekh. (2014). The west Andaman fault: A complex strain-partitioning boundary at the seaward edge of the Aceh basin, offshore sumatra. Tectonics, 33(5), 786-806. https://doi.org/10.1002/2013TC003475

Martinez, J. A., Castillo, J., \& Ortiz-Karpf, A. (2012). Evolución Tectono-Estratigrafica del Abanico del Magdalena, Caribe Colombiano. In XI Simposio Bolivariano - Exploración Petrolera en las Cuencas Subandinas.

Mauffret, A., \& Leroy, S. (1997). Seismic stratigraphy and structure of the Caribbean igneous province. Tectonophysics, 283(1-4), 61-104. https://doi.org/10.1016/S00401951(97)00103-0

McCaffrey, R. (1992). Oblique plate convergence, slip vectors, and forearc deformation. Journal of Geophysical Research, 97(92), 8905-8915.

McClay, K. R., Whitehouse, P. ., Dooley, T., \& Richards, M. (2004). 3D evolution of fold and thrust belts formed by oblique convergence. Marine and Petroleum Geology, 21(7), 857-877. https://doi.org/10.1016/j.marpetgeo.2004.03.009

Molinares, C. E., Martinez, J. I., Fiorini, F., Escobar, J., \& Jaramillo, C. (2012). Paleoenvironmental reconstruction for the lower Pliocene Arroyo Piedras section (Tubará - Colombia): Implications for the Magdalena River - paleodelta's dynamic. Journal of South American Earth Sciences, 39, 170-183. https://doi.org/10.1016/j.jsames.2012.04.007

Montes, C., Cardona, A., Jaramillo, C., Pardo, A., Silva, J. C., Valencia, V., et al. (2015). Middle Miocene closure of the Central American Seaway. Science, 348(6231), 226-229. https://doi.org/10.1126/science.aaa2815

Montes, Camilo, Guzmán, G., Bayona, G., Cardona, A., Valencia, V., \& Jaramillo, C. (2010). 
Clockwise rotation of the Santa Marta massif and simultaneous Paleogene to Neogene deformation of the Plato-San Jorge and Cesar-Ranchería basins. Journal of South American Earth Sciences, 29(4), 832-848. https://doi.org/10.1016/j.jsames.2009.07.010

Montes, Camilo, Bayona, G., Cardona, A., Buchs, D. M., Silva, C. A., Morón, S., et al. (2012). Arc-continent collision and orocline formation: Closing of the Central American seaway. Journal of Geophysical Research: Solid Earth, 117(4), 1-25. https://doi.org/10.1029/2011JB008959

Montes, Camilo, Cardona, A., McFadden, R., Morón, S. E. E., Silva, C. A. A., RestrepoMoreno, S., et al. (2012). Evidence for middle Eocene and younger land emergence in central Panama: Implications for Isthmus closure. Bulletin of the Geological Society of America, 124(5-6), 780-799. https://doi.org/10.1130/B30528.1

Mora-Bohórquez, J. A., Ibánez-Mejia, M., Oncken, O., de Freitas, M., Vélez, V., Mesa, A., \& Serna, L. (2017). Structure and age of the Lower Magdalena Valley basin basement, northern Colombia: New reflection-seismic and U-Pb-Hf insights into the termination of the central andes against the Caribbean basin. Journal of South American Earth Sciences, 74, 1-26. https://doi.org/10.1016/j.jsames.2017.01.001

Mora, A., Reyes-Harker, A., Rodriguez, G., Teson, E., Ramirez-Arias, J. C., Parra, M., et al. (2013). Inversion tectonics under increasing rates of shortening and sedimentation: Cenozoic example from the Eastern Cordillera of Colombia. Geological Society, London, Special Publications, 377(1), 411-442. https://doi.org/10.1144/SP377.6

Mora, J. A., Oncken, O., Le Breton, E., Ibánez-Mejia, M., Faccenna, C., Veloza, G., et al. (2017). Linking Late Cretaceous to Eocene Tectonostratigraphy of the San Jacinto Fold Belt of NW Colombia With Caribbean Plateau Collision and Flat Subduction. Tectonics, 36(11), 2599-2629. https://doi.org/10.1002/2017TC004612

Moreno-Sánchez, M., \& Pardo-Trujillo, A. (2003). Stratigraphical and Sedimentological Constraints on Western Colombia: Implications on the Evolution of the Caribbean Plate. In C. Bartolini, R. T. Buffler, \& J. Blickwede (Eds.), The Circum-Gulf of Mexico and the Caribbean: Hydrocarbon habitats, basin formation, and plate tectonics: AAPG Memoir (pp. 891-924).

Moreno, F., Hendy, A. J. W., Quiroz, L., Hoyos, N., Jones, D. S., Zapata, V., et al. (2015). Revised stratigraphy of Neogene strata in the Cocinetas Basin, La Guajira, Colombia. Swiss Journal of Palaeontology, 134(1), 5-43. https://doi.org/10.1007/s13358-0150071-4

Morley, C. K. (2003). Mobile shale related deformation in large deltas developed on passive and active margins. Geological Society, London, Special Publications, 216(1), 335-357.

Morley, C. K., \& Guerin, G. (1996). Comparison of gravity-driven deformation styles and behavior associated with mobile shales and salt. Tectonics, 15(6), 1154-1170.

Müller, R. D., Royer, J. Y., Cande, S. C., Roest, W. R., \& Maschenkov, S. (1999). New Constraints on the Late Cretaceous / Tertiary Plate Tectonic Evolution of the Caribbean. In P. Mann (Ed.), Caribbean Basins. Sedimentary Basins of the World, 4 (Vol. 4, pp. 33-59). Amsterdam: Elsevier B.V. https://doi.org/10.1016/S1874-5997(99)80036-7

Niño, H., Ojeda, G., Molinares, C. E., Torres, V., \& Suarez, M. (2006). Consideraciones para un Mapa Paleoambiental del Oligoceno, Cuenca del Valle Inferior del Magdalena, Colombia. In IX Simposio Bolivariano - Exploración Petrolera en las Cuencas Subandinas (p. 8 p). Cartagena, Colombia: Asociación Colombiana de Geólogos y Geofísicos del Petróleo (ACGGP).

Patiño, A. M., Parra, M., Ramírez, J. C., Sobel, E. R., Glodny, J., Almendral, A., \& Echeverri, S. (2019). Thermochronological constraints on Cenozoic exhumation along the southern Caribbean: The Santa Marta range, northern Colombia. In B. K. Horton \& A. Folguera (Eds.), Andean Tectonics (pp. 103-132). Elsevier. 
https://doi.org/10.1016/B978-0-12-816009-1.00007-1

Pennington, W. D. (1981). Subduction of the Eastern Panama Basin and Seismotectonics of Northwestern South America. Journal of Geophysical Research, 86(B11), 1075310770. https://doi.org/10.1029/JB086iB11p10753

Pérez, O. J., Bilham, R., Bendick, R., Velandia, J. R., Hernández, N., Moncayo, C., et al. (2001). Velocity field across the Southern Caribbean plate boundary and estimates of Caribbean/South-American plate motion using GPS geodesy 1994-2000. Geophysical Research Letters, 28(15), 2987-2990. https://doi.org/10.1029/2001GL013183

Pindell, J. L., \& Kennan, L. (2009). Tectonic evolution of the Gulf of Mexico, Caribbean and northern South America in the mantle reference frame: an update. Geological Society, London, Special Publications, 328(1), 1-55. https://doi.org/10.1144/SP328.1

Pindell, J. L., Cande, S. ., Pitman, W. C., Rowley, D. B., Dewey, J. F., Labrecque, J., \& Haxby, W. (1988). A plate-kinematic framework for models of Caribbean evolution. Tectonophysics, 155(1-4), 121-138. https://doi.org/10.1016/0040-1951(88)90262-4

Pindell, J. L., Higgs, R., \& Dewey, J. F. (1998). Cenozoic palinspastic reconstruction, paleogeographic evolution and hydrocarbon setting of the northern margin of South America. In J. L. Pindell \& C. Drake (Eds.), Paleogeographic Evolution and Nonglacial Eustasy, Northern South America. (pp. 45-85). SEPM (Society for Sedimentary Geology), Special Publication No. 58.

Piraquive, A., Pinzón, E., Kammer, A., Bernet, M., \& von Quadt, A. (2018). Early Neogene unroofing of the Sierra Nevada de Santa Marta, as determined from detrital geothermochronology and the petrology of clastic basin sediments. GSA Bulletin, 130(3-4), 355-380. https://doi.org/10.1130/B31676.1

Platt, J. P. (1993). Mechanics of Oblique Convergence. Journal of Geophysical Research, 98(B9), 16239-16256. https://doi.org/10.1029/93JB00888

Reinoza, C., Jouanne, F., Audemard, F. A., Schmitz, M., \& Beck, C. (2015). Geodetic exploration of strain along the El Pilar Fault in northeastern Venezuela. Journal of Geophysical Research: Solid Earth, n/a-n/a. https://doi.org/10.1002/2014JB011483

Restrepo-Correa, I. C., \& Ojeda, G. Y. (2010). Geologic controls on the morphology of La Aguja submarine canyon. Journal of South American Earth Sciences, 29(4), 861-870. https://doi.org/10.1016/j.jsames.2010.07.001

Reyes-Harker, A., Montenegro, G., \& Gómez, P. (2000). Evolución tectonoestratigráfica del Valle Inferior del Magdalena, Colombia. In VII Simposio Bolivariano - Exploración Petrolera en las Cuencas Subandinas (pp. 293-309). Caracas, Venezuela: Asociación Colombiana de Geólogos y Geofísicos del Petróleo.

Reyes-Harker, A., Ruiz-Valdivieso, C. F., Mora, A., Ramírez-Arias, J. C., Rodriguez, G., De La Parra, F., et al. (2015). Cenozoic paleogeography of the Andean foreland and retroarc hinterland of Colombia. AAPG Bulletin, 99(08), 1407-1453. https://doi.org/10.1306/06181411110

Rincón, D. A., Arenas, J. E., Cuartas, C. H., Cárdenas, A. L., Molinares, C. E., Caicedo, C., \& Jaramillo, C. (2007). Eocene-Pliocene planktonic foraminifera biostratigraphy from the continental margin of the southwest Caribbean. Stratigraphy, 4(4), 261-311. Retrieved from http://www.stri.si.edu/sites/publications/PDFs/SW_RinconD_2007_StratigraphyFColom bia.pdf

Romero, G. (2009). Deepwater sedimentary processes in an active margin, Magdalena submarine fan, offshore Colombia. University of Oklahoma, PhD Thesis.

Romero-Otero, G. A., Slatt, R. M., \& Pirmez, C. (2010). Detached and Shelf-Attached Mass Transport Complexes on the Magdalena Deepwater Fan. In D. C. Mosher, R. C. Shipp, L. Moscardelli, J. D. Chaytor, C. D. P. Baxter, H. J. Lee, \& R. Urgeles (Eds.), 
Submarine Mass Movements and Their Consequences. Advances in Natural and Technological Hazards Research, Vol. 28 (pp. 593-606). Dordrecht: Springer

Netherlands. https://doi.org/10.1007/978-90-481-3071-9

Ruiz, C., Davis, N., Bentham, P., Price, A., \& Carvajal, D. (2000). Structure and tectonic evolution of the South Caribbean Basin, Southern Offshore Colombia: a progressive accretionary prism. In VII Simposio Bolivariano - Exploración Petrolera en las Cuencas Subandinas (p. 22). Caracas, Venezuela: Asociación Colombiana de Geólogos y Geofísicos del Petróleo (ACGGP).

Ryan, H. F., \& Scholl, D. W. (1989). The evolution of forearc structures along an oblique convergent margin, central Aleutian Arc. Tectonics, 8(3), 497-516. https://doi.org/10.1029/TC008i003p00497

Sanchez-Rojas, J., \& Palma, M. (2014). Crustal density structure in northwestern South America derived from analysis and 3-D modeling of gravity and seismicity data. Tectonophysics, 634, 97-115. https://doi.org/10.1016/j.tecto.2014.07.026

Sanchez, J., \& Mann, P. (2015). Integrated Structural and Basinal Analysis of the CesarRancheria Basin, Colombia: Implications for its Tectonic History and Petroleum Systems. In Claudio Bartolini \& P. Mann (Eds.), Memoir 108: Petroleum Geology and Potential of the Colombian Caribbean Margin (pp. 431-470). AAPG. https://doi.org/10.1306/13531945M1083648

Schubert, C. (1984). Basin formation along the Bocono-Moron-El Pilar Fault System, Venezuela. Journal of Geophysical Research, 89(B7), 5711. https://doi.org/10.1029/JB089iB07p05711

Shepard, F. P., Dill, R. F., Heezen, B. C., Dill Rf, \& Heezen Bc. (1968). Diapiric Intrusions in Foreset Slope Sediments Off Mafdalena Delta, Colombia. American Association of Petroleum Geologists Bulletin, 52(11 pt 1), 21972207. https://doi.org/10.1306/5D25C55F-16C1-11D7-8645000102C1865D

Soto, J. I., Fernández-lbáñez, F., Talukder, A. R., \& Martínez-García, P. (2010). Miocene shale tectonics in the northern Alboran Sea (Western Mediterranean). AAPG Memoir, 93(93), 119-144. https://doi.org/10.1306/13231312M933422

Spikings, R., \& Simpson, G. (2014). Rock uplift and exhumation of continental margins by the collision, accretion, and subduction of buoyant and topographically prominent oceanic crust. Tectonics, 33(5), 635-655. https://doi.org/10.1002/2013TC003425

Sylvester, Z., Cantelli, A., \& Pirmez, C. (2015). Stratigraphic evolution of intraslope minibasins: Insights from surface-based model. AAPG Bulletin, 99(6), 1099-1129. https://doi.org/10.1306/01081514082

Symithe, S., Calais, E., de Chabalier, J. B., Robertson, R., \& Higgins, M. (2015). Current block motions and strain accumulation on active faults in the Caribbean. Journal of Geophysical Research: Solid Earth, 120(5), 3748-3774. https://doi.org/10.1002/2014JB011779

Syracuse, E. M., Maceira, M., Prieto, G. A., Zhang, H., \& Ammon, C. J. (2016). Multiple plates subducting beneath Colombia, as illuminated by seismicity and velocity from the joint inversion of seismic and gravity data. Earth and Planetary Science Letters, 444, 139-149. https://doi.org/10.1016/j.epsl.2016.03.050

Taboada, A., Rivera, L. A., Fuenzalida, A., Cisternas, A., Philip, H., Bijwaard, H., et al. (2000). Geodynamics of the northern Andes. Tectonics, 19(5), 787-813.

De Toni, B., \& Kellogg, J. (1993). Seismic evidence for blind thrusting of the northwestern flank of the Venezuelan Andes. Tectonics, 12(6), 1393-1409. https://doi.org/10.1029/93TC01893

Toro, J. (1990). The Termination of the Bucaramanga Fault in the Cordillera Oriental, Colombia. University of Arizona, MSc Thesis. 
Trenkamp, R., Kellogg, J. N., Freymueller, J. T., \& Mora, H. P. (2002). Wide plate margin deformation, southern Central America and northwestern South America, CASA GPS observations. Journal of South American Earth Sciences, 15(2), 157-171. https://doi.org/10.1016/S0895-9811(02)00018-4

Tschanz, C. M., Marvin, R. F., Cruz B., J., Mehnert, H. H., \& Cebula, G. T. (1974). Geologic Evolution of the Sierra Nevada de Santa Marta, Northeastern Colombia. Geological Society of America Bulletin, 85(2), 273. https://doi.org/10.1130/00167606(1974)85<273:GEOTSN>2.0.CO;2

Vallejo, C., Spikings, R. a., Luzieux, L., Winkler, W., Chew, D., \& Page, L. (2006). The early interaction between the Caribbean Plateau and the NW South American Plate. Terra Nova, 18(4), 264-269. https://doi.org/10.1111/j.1365-3121.2006.00688.x

Vence, E. M. (2008). Subsurface structure, stratigraphy, and regional tectonic controls of the Guajira margin of northern Colombia: University of Texas at Austin, MSc Thesis.

Vernette, G., Mauffret, A., Bobier, C., Briceno, L., \& Gayet, J. (1992). Mud diapirism, fan sedimentation and strike-slip faulting, Caribbean Colombian Margin. Tectonophysics, 202(1), 335-349. https://doi.org/10.1016/0040-1951(92)90118-P

Villagómez, D., Spikings, R., Mora, A., Guzmán, G., Ojeda, G., Cortés, E., \& Van Der Lelij, R. (2011). Vertical tectonics at a continental crust-oceanic plateau plate boundary zone: Fission track thermochronology of the Sierra Nevada de Santa Marta, Colombia. Tectonics, 30(4), 18. https://doi.org/10.1029/2010TC002835

Villamil, T. (1999). Campanian-Miocene tectonostratigraphy, depocenter evolution and basin development of Colombia and western Venezuela. Palaeogeography, Palaeoclimatology, Palaeoecology, 153(1-4), 239-275. https://doi.org/10.1016/S00310182(99)00075-9

Weber, J. C., Dixon, T. H., DeMets, C., Ambeh, W. B., Jansma, P., Mattioli, G., et al. (2001). GPS estimate of relative motion between the Caribbean and South American plates, and geologic implications for Trinidad and Venezuela. Geology, 29(1), 75-78. https://doi.org/10.1130/0091-7613(2001)029<0075:GEORMB>2.0.CO;2

Weber, M., Cardona, A., Valencia, V., García-Casco, A., Tobón, M., \& Zapata, S. (2010). $\mathrm{U} / \mathrm{Pb}$ detrital zircon provenance from late cretaceous metamorphic units of the Guajira Peninsula, Colombia: Tectonic implications on the collision between the Caribbean arc and the South American margin. Journal of South American Earth Sciences, 29(4), 805816. https://doi.org/10.1016/j.jsames.2009.10.004

Wright, J. E., \& Wyld, S. J. (2011). Late Cretaceous subduction initiation on the eastern margin of the Caribbean-Colombian Oceanic Plateau: One Great Arc of the Caribbean (?). Geosphere, 7(2), 468-493. https://doi.org/10.1130/GES00577.1

Yu, G., Wesnousky, S. G., \& Ekstrom, G. (1993). Slip Partitioning along Major Convergent Plate Boundaries. Pure and Applied Geophysics, 140(2), 183-210. https://doi.org/10.1007/BF00879405

Zapata, S., Cardona, A., Montes, C., Valencia, V., Vervoort, J., \& Reiners, P. (2014). Provenance of the Eocene Soebi Blanco formation, Bonaire, Leeward Antilles: Correlations with post-Eocene tectonic evolution of northern South America. Journal of South American Earth Sciences, 52, 179-193. https://doi.org/10.1016/j.jsames.2014.02.009

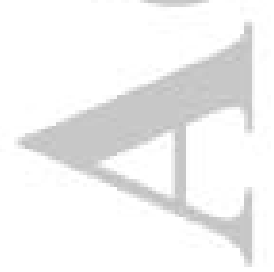




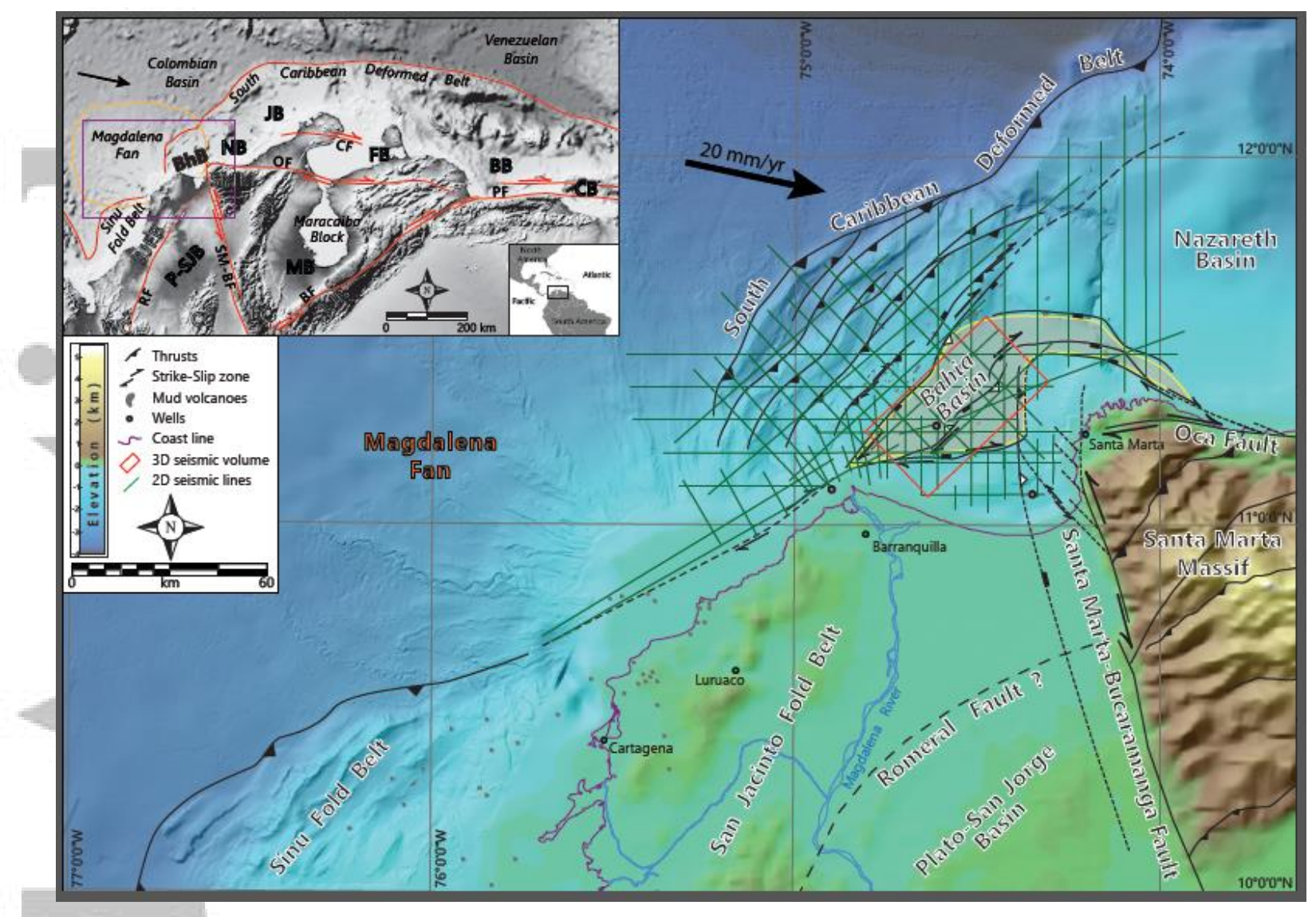

Figure 1. Maps of the southern Caribbean margin and the north-western corner of South America. Inset map shows the regional tectonic setting, and highlights main basins and structures. The Bahia Basin (BhB) is located in front of the NW corner of the Maracaibo Block, at the termination of two regional strike-slip fault systems: the E-W trending Oca-El Pilar Fault System (OF, PF), and the NW-SE trending Santa Marta-Bucaramanga Fault (SM-BF). CB, Cariaco Basin; BB, Bonaire Basin; FB, Falcon Basin; JB, Jarara Basin; NB, Nazareth Basin; MB, Maracaibo Basin; P-SJB, Plato-San Jorge Basin; CC, Central Cordillera; EC, Eastern Cordillera; MR, Merida Range; PR, Perija Range; SMM, Santa Marta Massif; GP, Guajira Peninsula; RF, Romeral Fault; BF, Bocono Fault; CF, Cuisa Fault. Caribbean Plate velocity (black arrow) from Trenkamp et al. (2002).

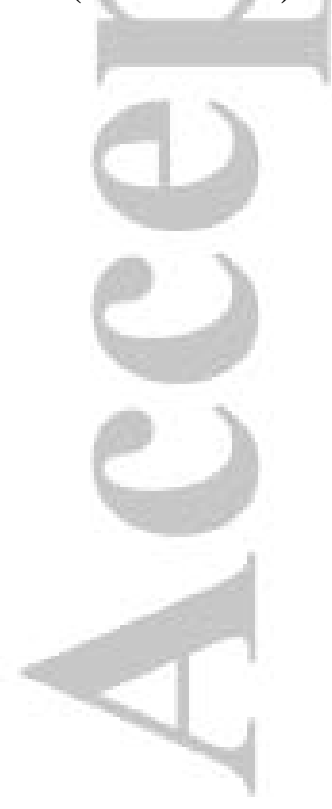




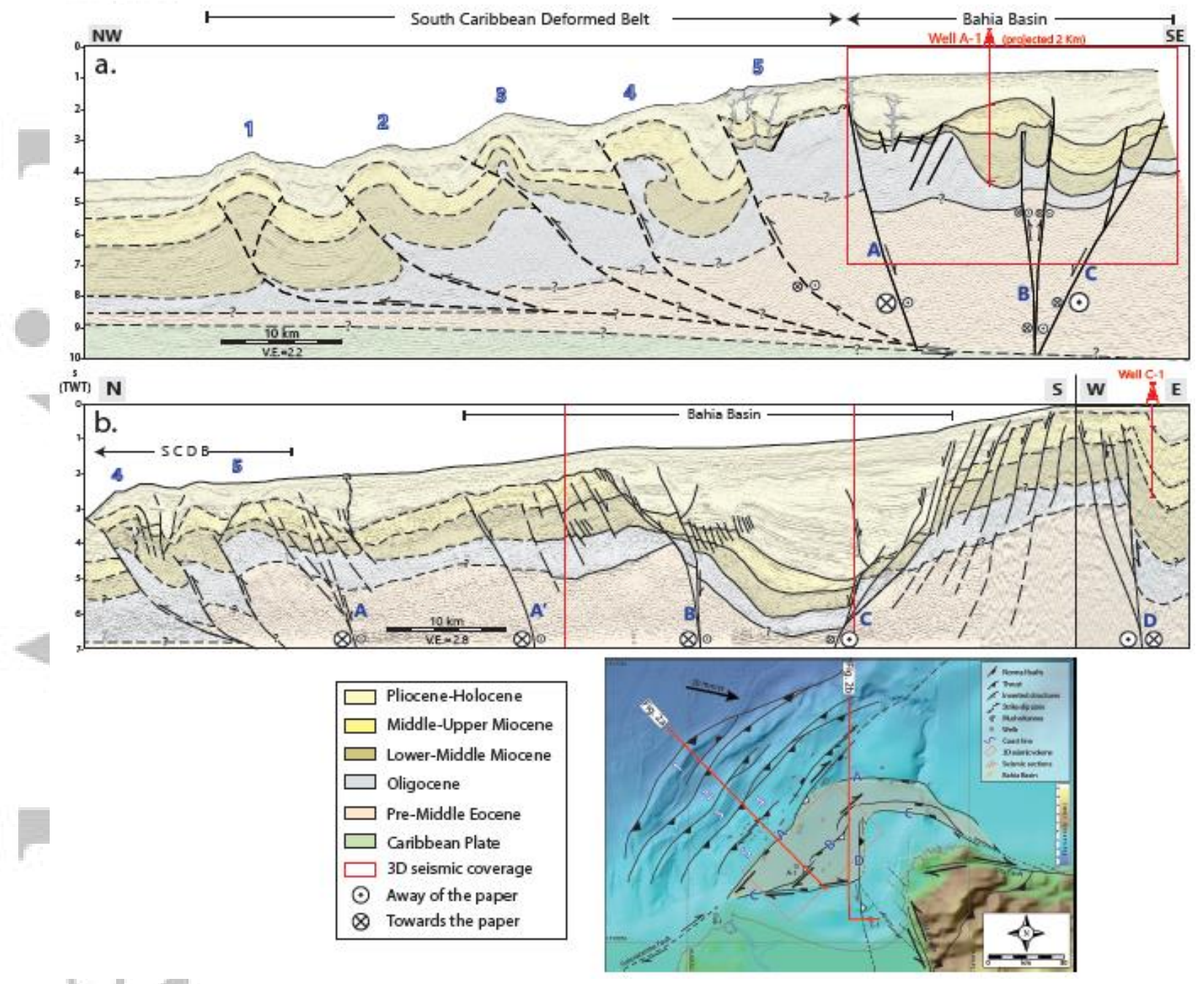

Figure 2. a.) NW-SE 2D seismic line AC-1999-G7, showing the compressional deformation within the South Caribbean Deformed Belt formed by 5 main thrust towards the NW, and the occurrence of the Bahia Basin towards the SE. b.) 2D lines L-1982-5300, L-1984-352 (N-S) and L-1984-601 (W-E) showing the eastern part of the Bahia Basin and the intersection between Faults $C$ and D. Fault D displays younger activity as an inversion fault with left-lateral displacement and affecting the southeastern region of the basin. Inset map shows the outline of the Bahia Basin. Numbers refer to main thrusts within the South Caribbean Deformed Belt. Faults A-A', C and D are the boundaries of the Bahia Basin. The uninterpreted versions of the seismic lines are included as supporting information (Figure S2). 


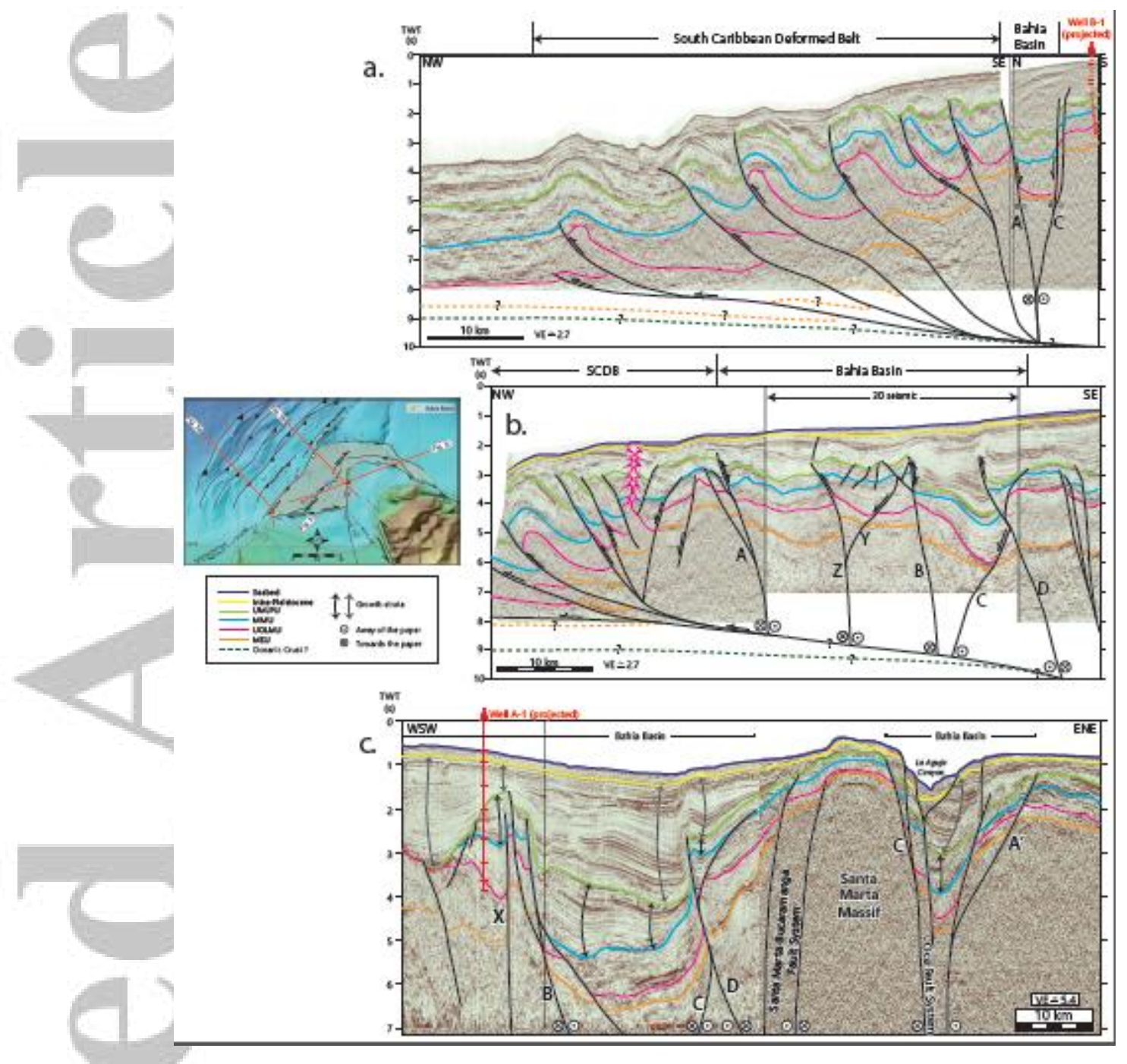

Figure 3. a.) 2D regional lines AC-1999-G13 (NW-SE) and L-1984-316 (N-S). This section illustrates the south-westernmost extension of Faults A and C located at the rear of the South Caribbean Deformed Belt. Both faults are deep-rooted into the subduction zone and are the boundaries of the narrow Bahia Basin. B-1 well is projected $12 \mathrm{~km}$, and helps to tie upper Miocene, middle Miocene and upper Oligocene unconformities. b.) 2D line AC-1999-G1 merged with 3D seismic volume. Fault A is the north-western boundary of the basin; although it displays a normal displacement, folding of Miocene strata implies some inversion along the fault. Fault $\mathrm{C}$ is the southern boundary of the basin, although it is affected by the latest displacement along Fault D. The Bahia Fault (B) is the main intrabasinal fault and bounds a main depocenter towards the south-eastern side of the basin. c.) 3D seismic merged with 2D line L-1975-21. This illustrates the Santa Marta Massif bounded by two strike-slip fault systems, and the presence of the Bahia Basin on both sides. Growth strata and shifting depositional axes support the continuous control of the Bahia Basin bounding faults. The uninterpreted versions of the seismic lines are included as supporting information (Figure $\mathbf{S 3}$ ). 


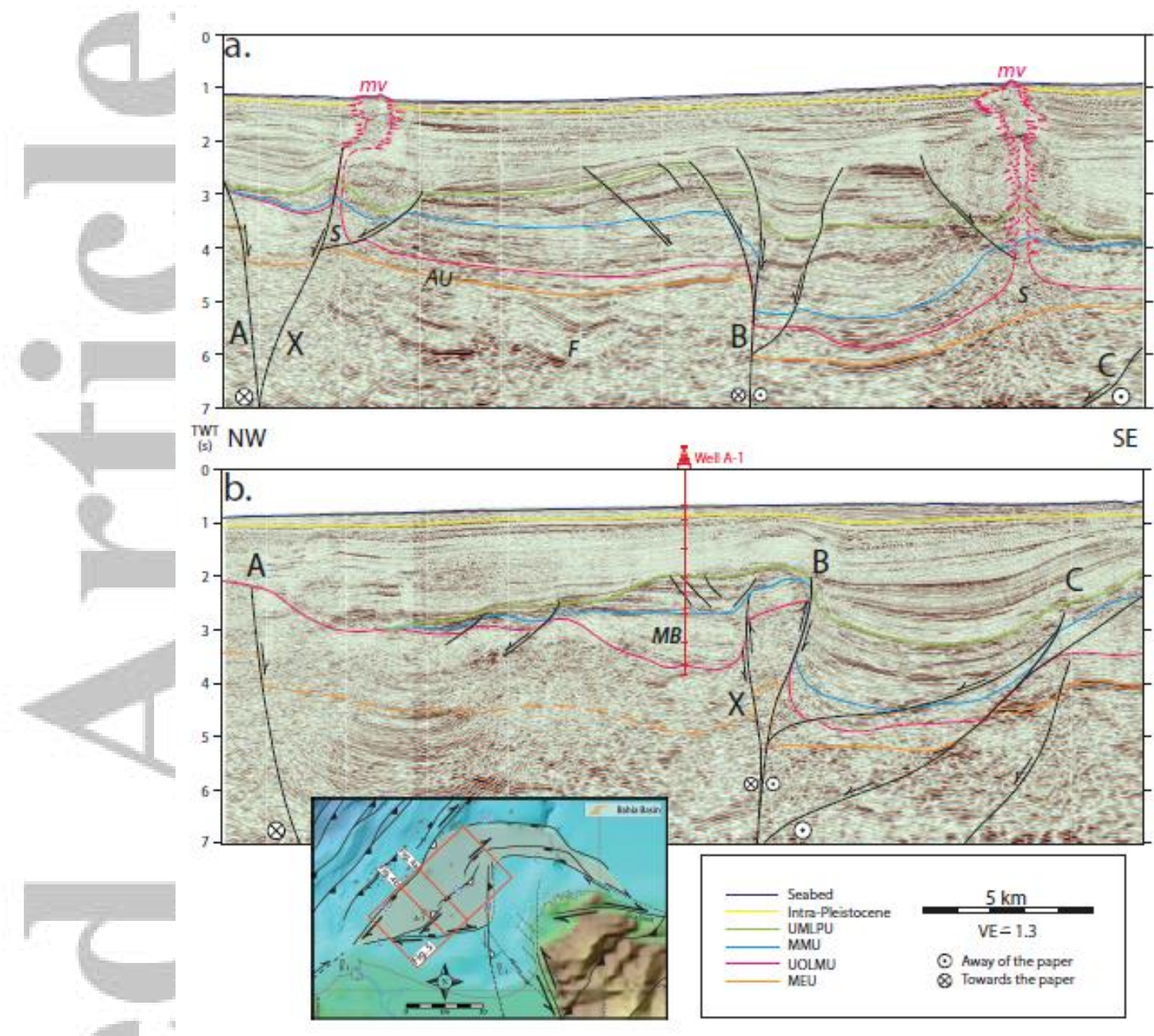

Figure 4. a.) In-line section crossing the central area of the survey, over a relay zone between the southern and central highs, where the Bahia Fault zone (B) is composed of two normal faults dipping to the SE. The upper Miocene to lower Pliocene unconformity (UMLPU, green) and the middle Miocene unconformity (MMU, blue) are interpreted between the step-faulted blocks. Deeper, the upper Oligocene to lower Miocene unconformity (UOLMU, magenta) is interpreted as the top of the overpressured shale source (S) of the mud volcanism (mv). The orange line is interpreted as the older regional unconformity (Middle Eocene, MEU) defined by the angular unconformity (AU) between planar reflections above and folded non-continuous reflections below (F), presumably the San Jacinto Fold Belt. b.) In-line section crossing the location of the A-1 well. The UMLPU (green) is relatively easy to interpret on the northern side of the Bahia Fault (B). Towards the SE, the UMLPU lies within a depocenter bounded by two highs; here, it is difficult to pick the location of the UMLPU because of the normal and inverse displacement of the Bahia Fault although 3D observations confirm this interpretation. Deeper, the thickening of the Oligocene section towards the NW occurs in response to the shale movement and the development of a down-building minibasin (MB) towards the axis of the Bahia Basin (see further discussion in section 7 and Figure 8). This thickening may affect the seismic response of deeper units and hinder the interpretation of the MEU (dashed orange) in this sector. The uninterpreted versions of the seismic lines are included as supporting information (Figure S4). 


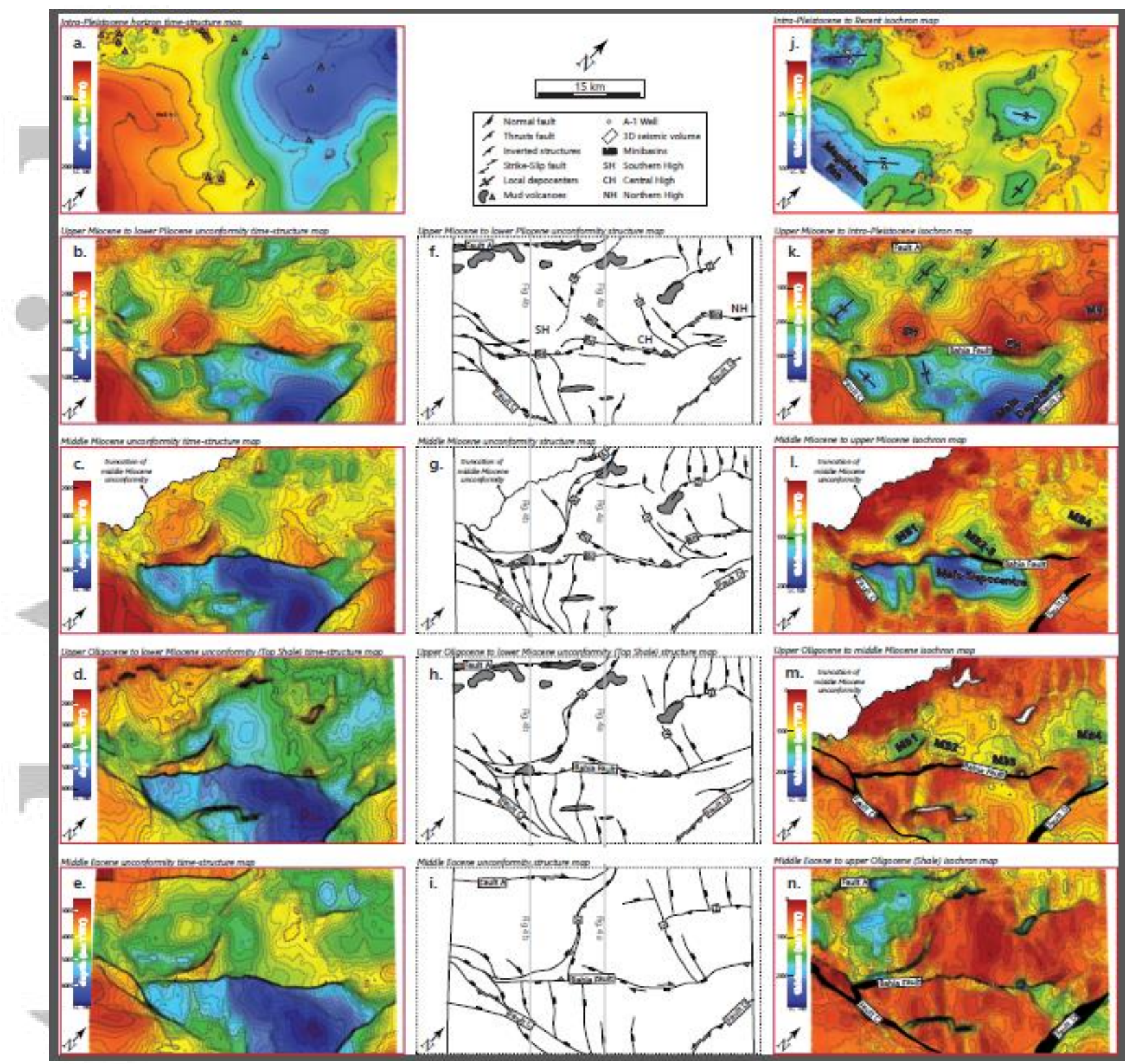

Figure 5. Time-structure maps (a-e), schematic structure maps (f-i) and isochron maps (j-n), interpreted from the 3D seismic data in the Bahia Basin. a.) Intra-Pleistocene (IP) timestructure map; b.) Upper Miocene to lower Pliocene unconformity (UMLPU) time-structure map; c.) Middle Miocene unconformity (MMU) time-structure map; d.) Upper Oligocene to lower Miocene unconformity (UOLMU) time-structure map; e.) Middle Eocene unconformity (MEU) time-structure map; f.) UMLPU structure map; g.) MMU structure map; h.) UOLMU structure map; i.) MEU structure map; j.) IP to Recent isochron map; k.) UMLPU to IP isochron map; 1.) MMU to UMLPU isochron map; m.) UOLMU to MMU isochron map; n.) MEU to UOLMU isochron map. 

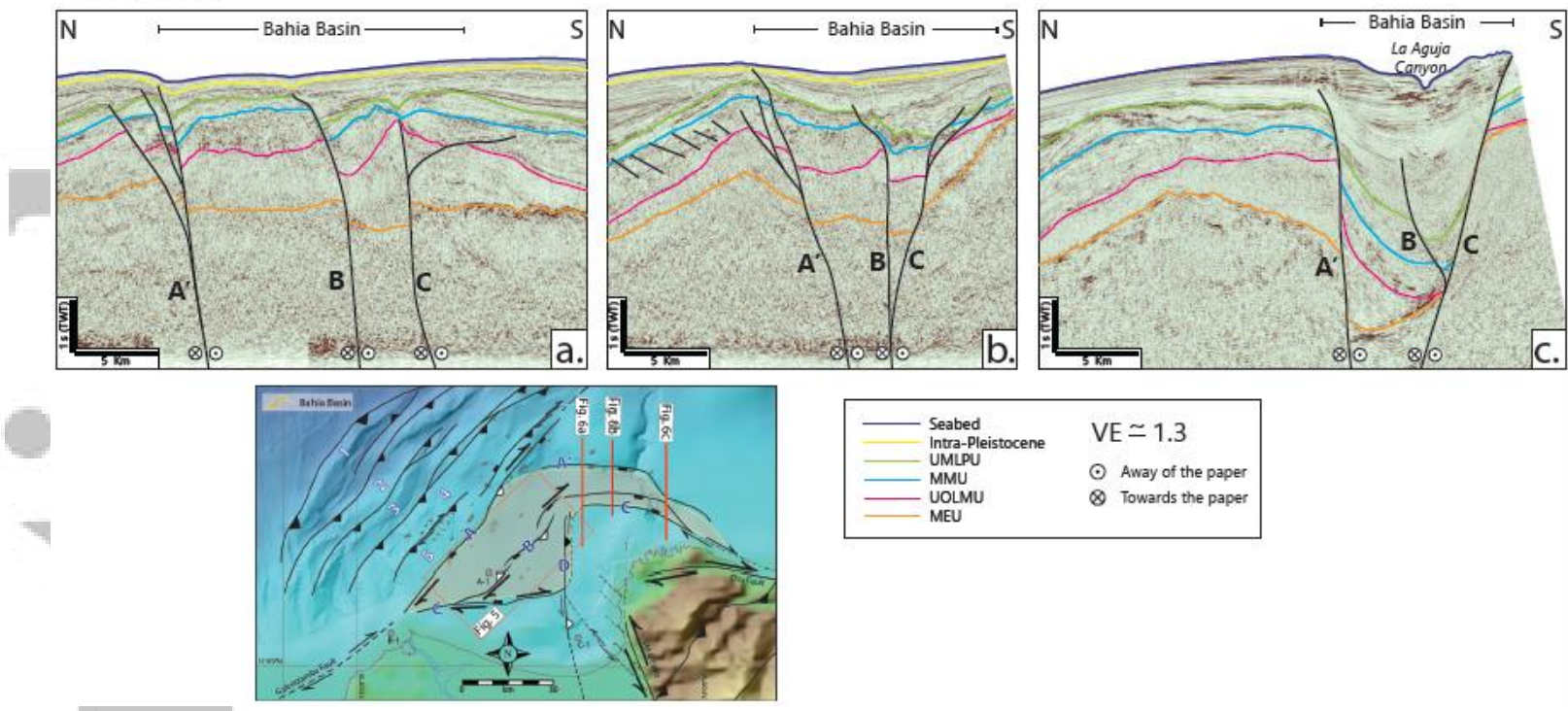

Figure 6. 2D seismic lines to the NE of Fault D, showing the eastern extension of the Bahia Basin. The Bahia Basin strikes E-W, narrowing towards the east, and is bounded by three steep faults with normal offsets in approximately the same geometry as Faults A, B and C to the west. a.) L-1982-5500 shows a shallow Bahia Basin; b.) L-1982-5700 shows the narrowing of the basin; c.) NZ-1999-127 shows the easternmost section of the basin as it joins the Oca Fault System and seems to control the La Aguja Canyon. The uninterpreted versions of the seismic lines are included as supporting information (Figure S5).

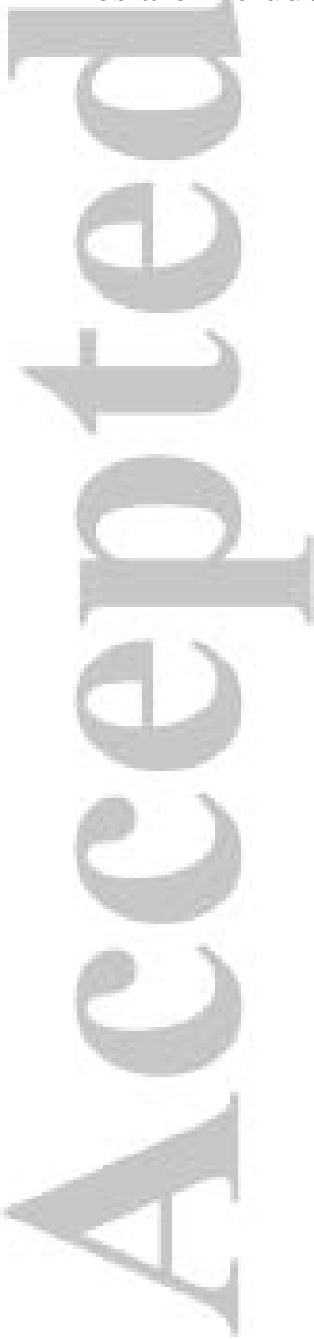



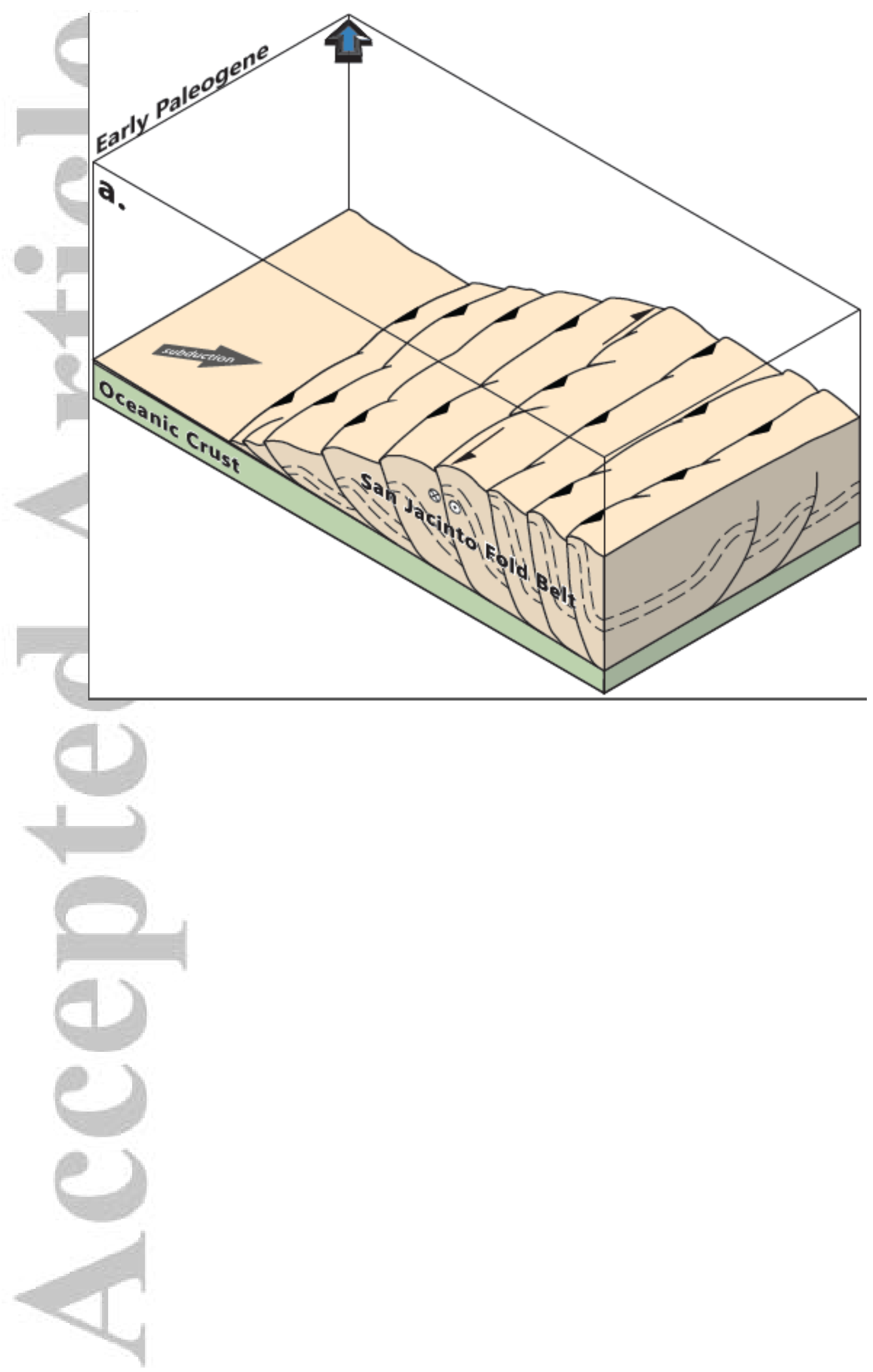

(C2019 American Geophysical Union. All rights reserved. 


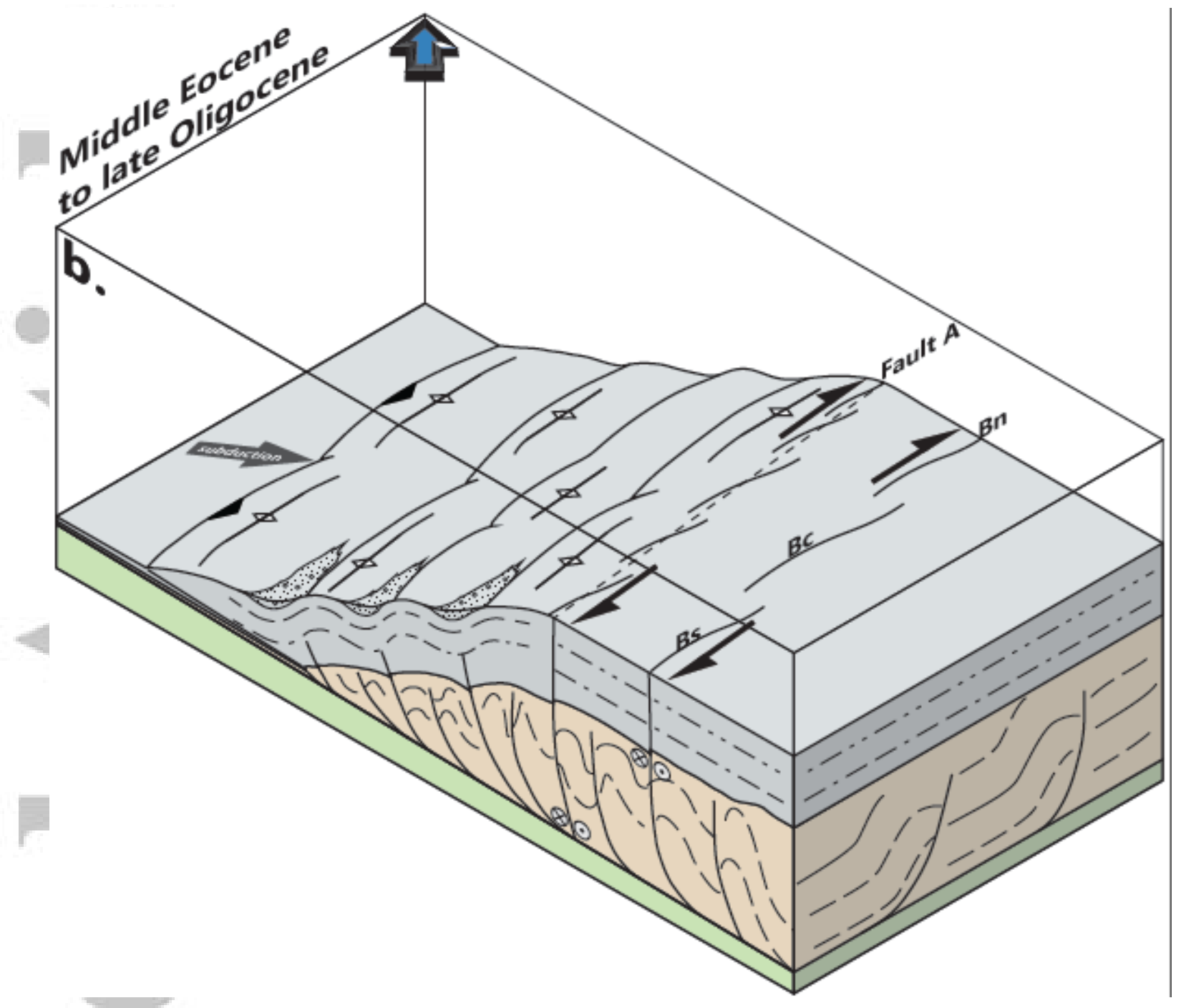




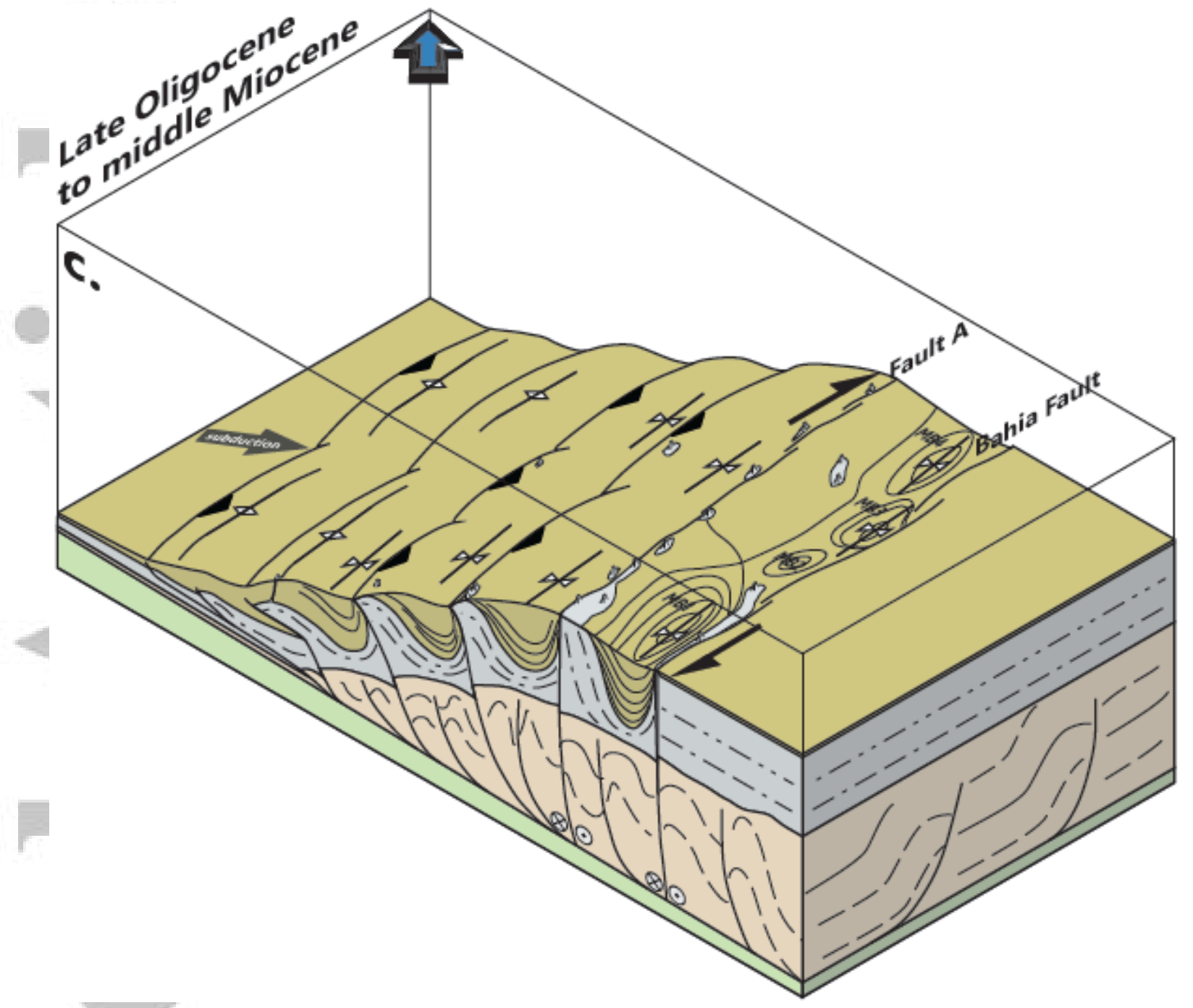




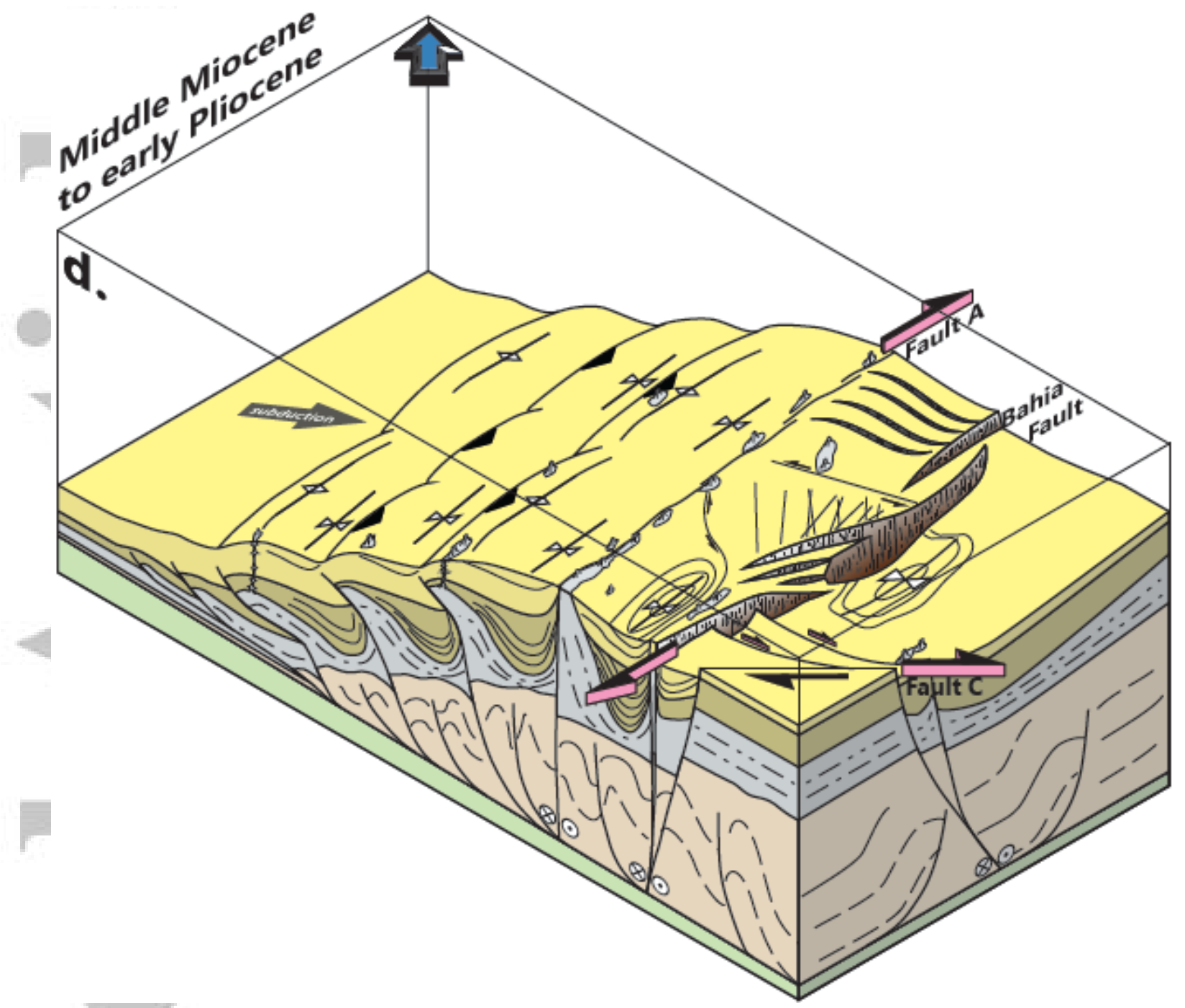

(C2019 American Geophysical Union. All rights reserved. 


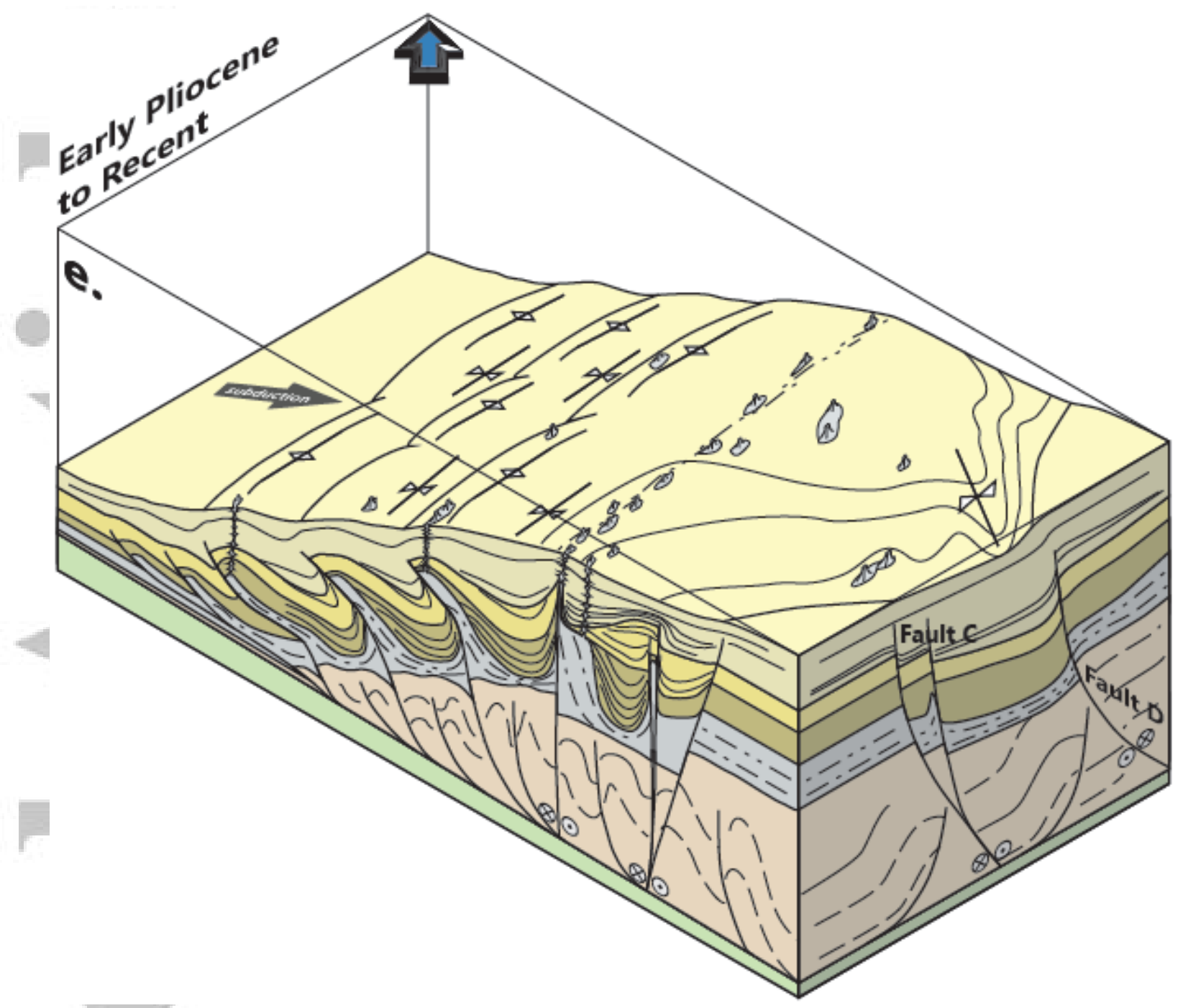

Figure 7. Schematic block diagrams showing the Bahia Basin evolution. a.) Early Paleogene; formation of the San Jacinto Fold Belt as a result of subduction of the Caribbean Plate. b.) Middle Eocene to late Oligocene; unconformable deposition of a shaly-rich unit over the San Jacinto Fold Belt. Oblique subduction induces the formation of right-lateral strike-slip faults at the rear of the accretionary prism. c.) Late Oligocene to middle Miocene; strike-slip continues and the Bahia Basin is formed between Fault A and the Bahia fault. The sediment load induces shale mobility and mud volcanism. d.) Middle Miocene to early Pliocene; as strike-slip deformation continues, normal faulting and mud withdrawal continues at the axis of the basin. e.) Early Pliocene to Recent; deposition is shifted towards the SE of the Bahia Fault, followed by basin inversion.

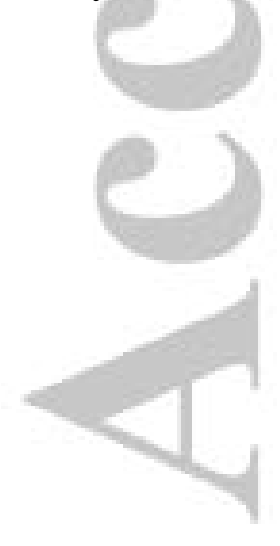



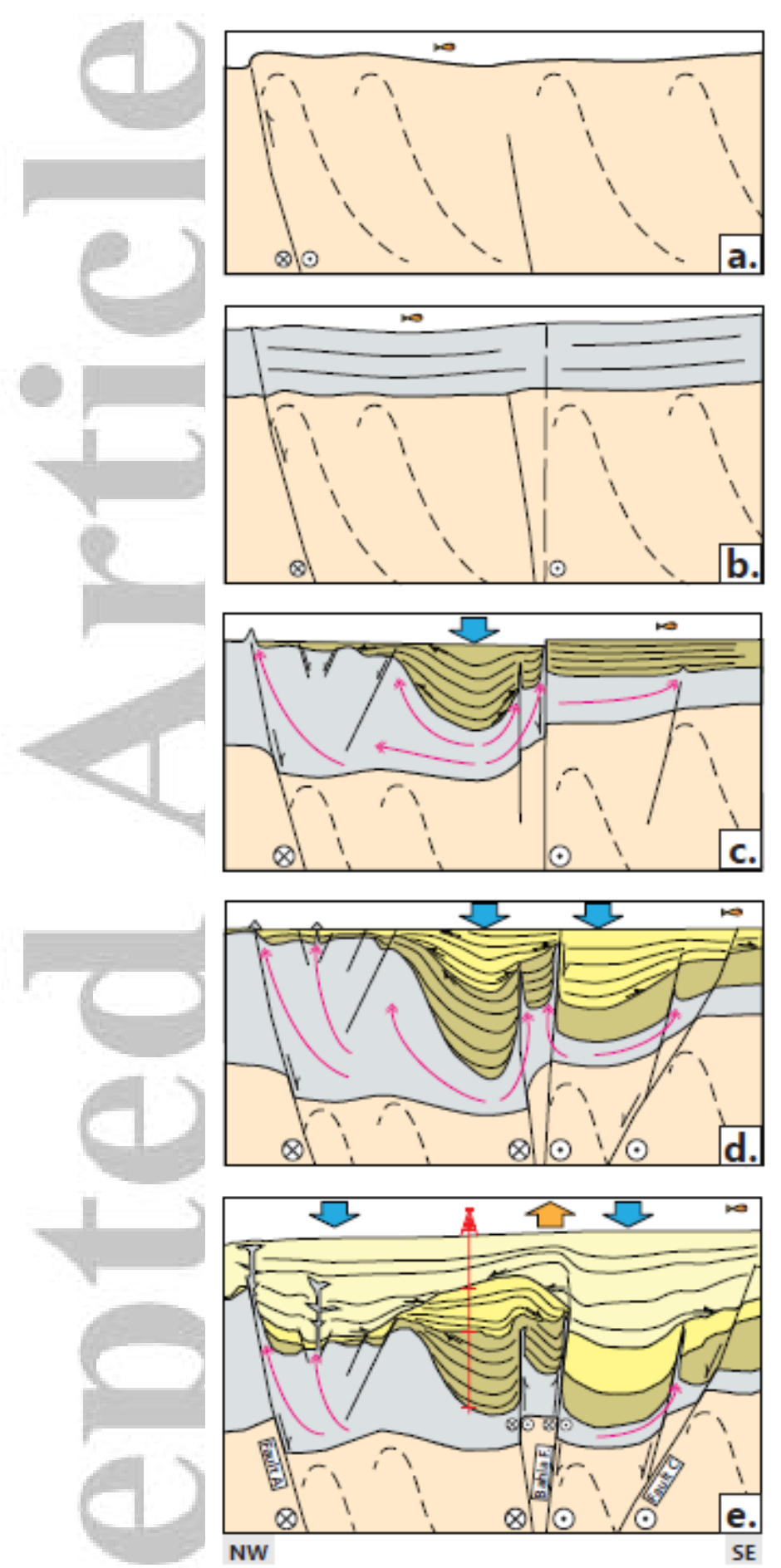

$\not / y$ Normal Fault
Reverse Fault
Away of the paper
$\otimes$ Towards the paper
Downbulding depocentre
Anticline growth
Seismic truncation
Shale mobilization
$\checkmark$ Mud volcanoes
$\square$ Plio-Pleistocene
$\square$ Middle Miocene-late Miocene
$\square$ Late Oligocene-middle Miocene
$\square$ Middle Eocene-Oligocene (Shale)

Figure 8. Schematic, cross-section evolution of the Bahia Basin illustrates the influence of shale tectonics. a.) Pre-middle Eocene, accretionary prism (San Jacinto Fold Belt). b.) Deposition of deepwater pelagic shales during middle Eocene to late Oligocene times. c.) Late Oligocene to middle Miocene, formation of the Bahia Basin between faults A and Bahia produces localized deposition of sediments, resulting in shale mobilization and downbuilding minibasin formation. d.) Deposition during middle to upper Miocene times continued the development of minibasins at both sides of the Bahia Fault. e.) At Plio-Pleistocene times, the activation of a popup structure along the Bahia Fault produces the partial inversion of the NW minibasin and the growth of an anticline structure flanked by depocenters. 


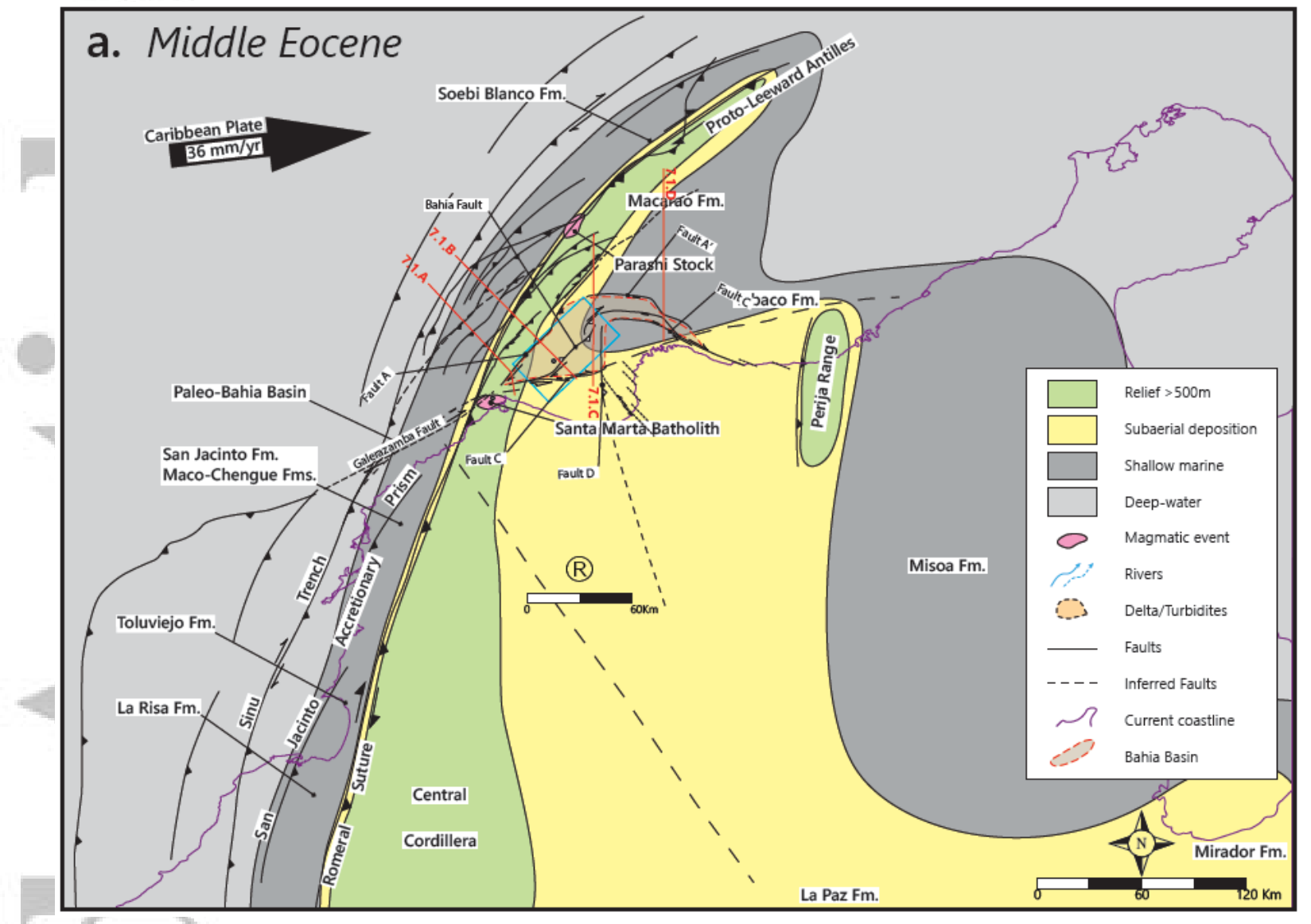




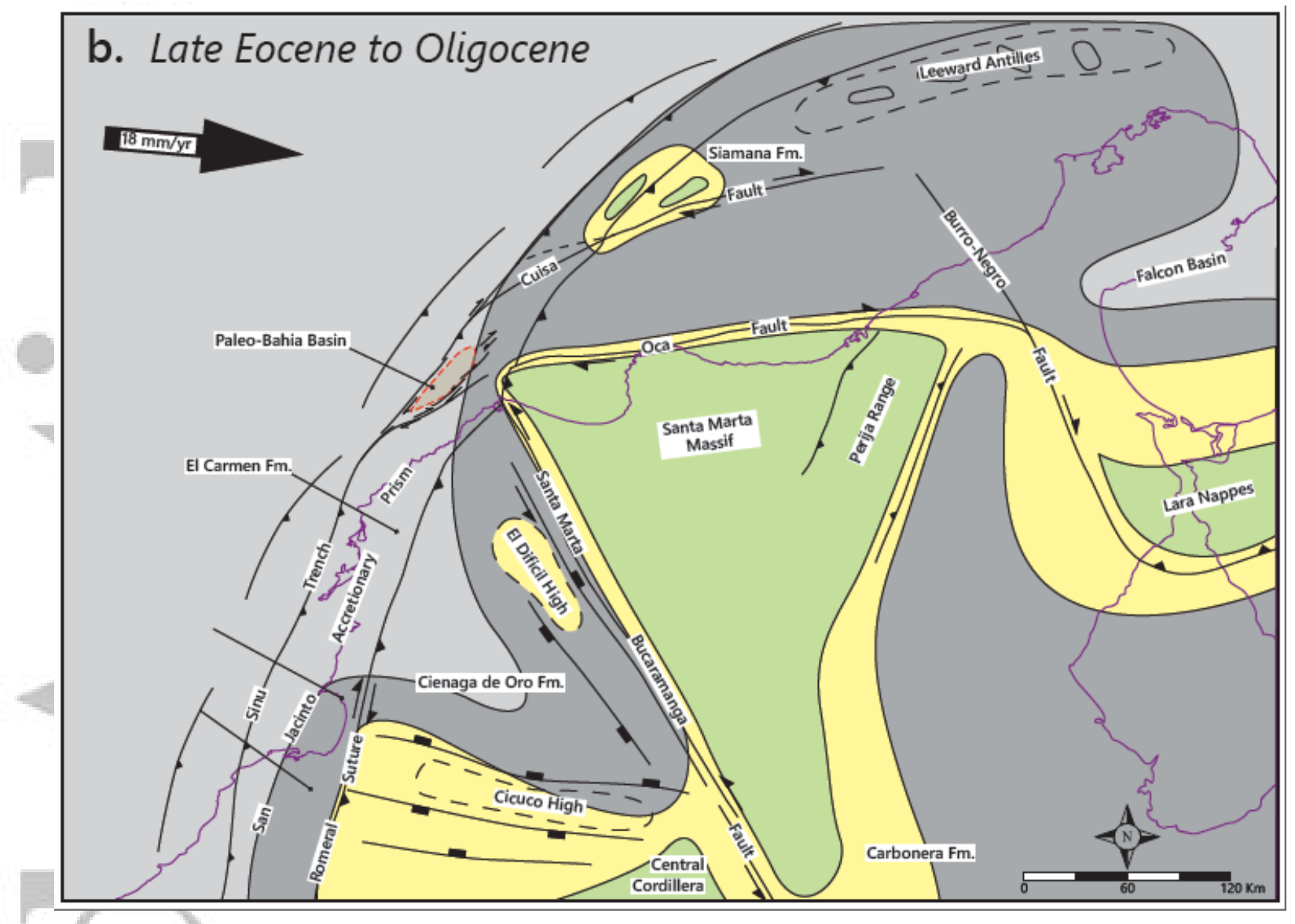




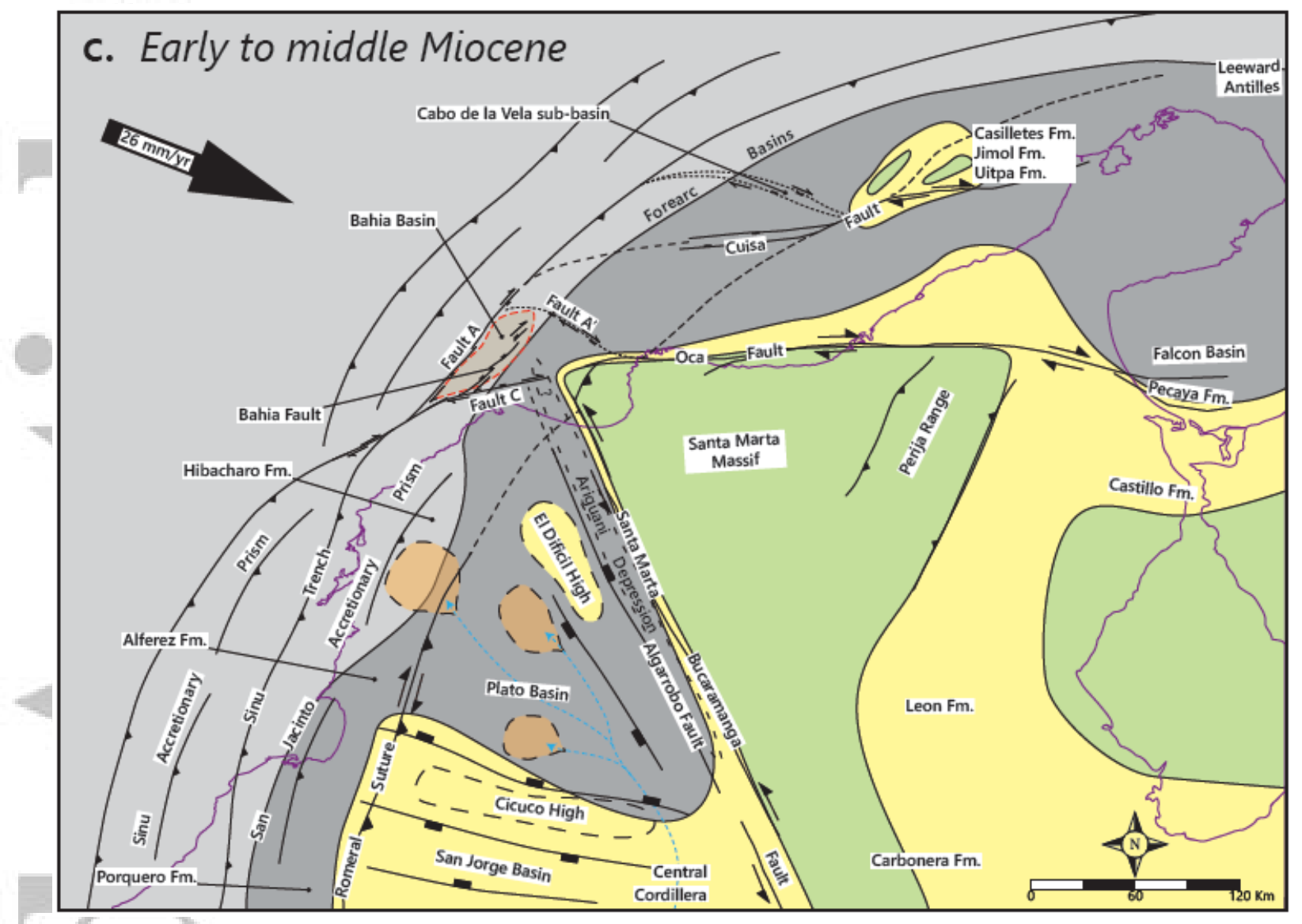




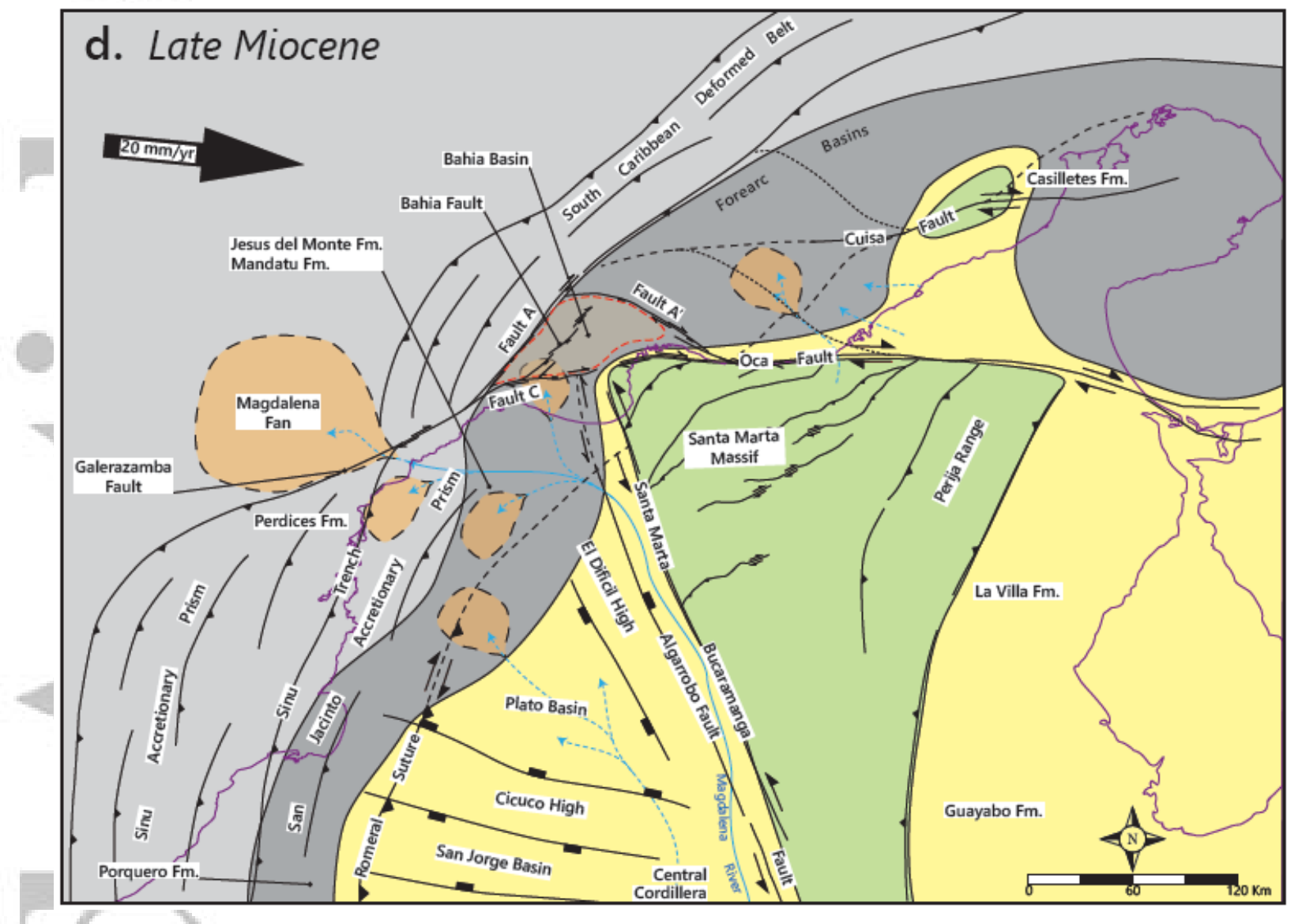




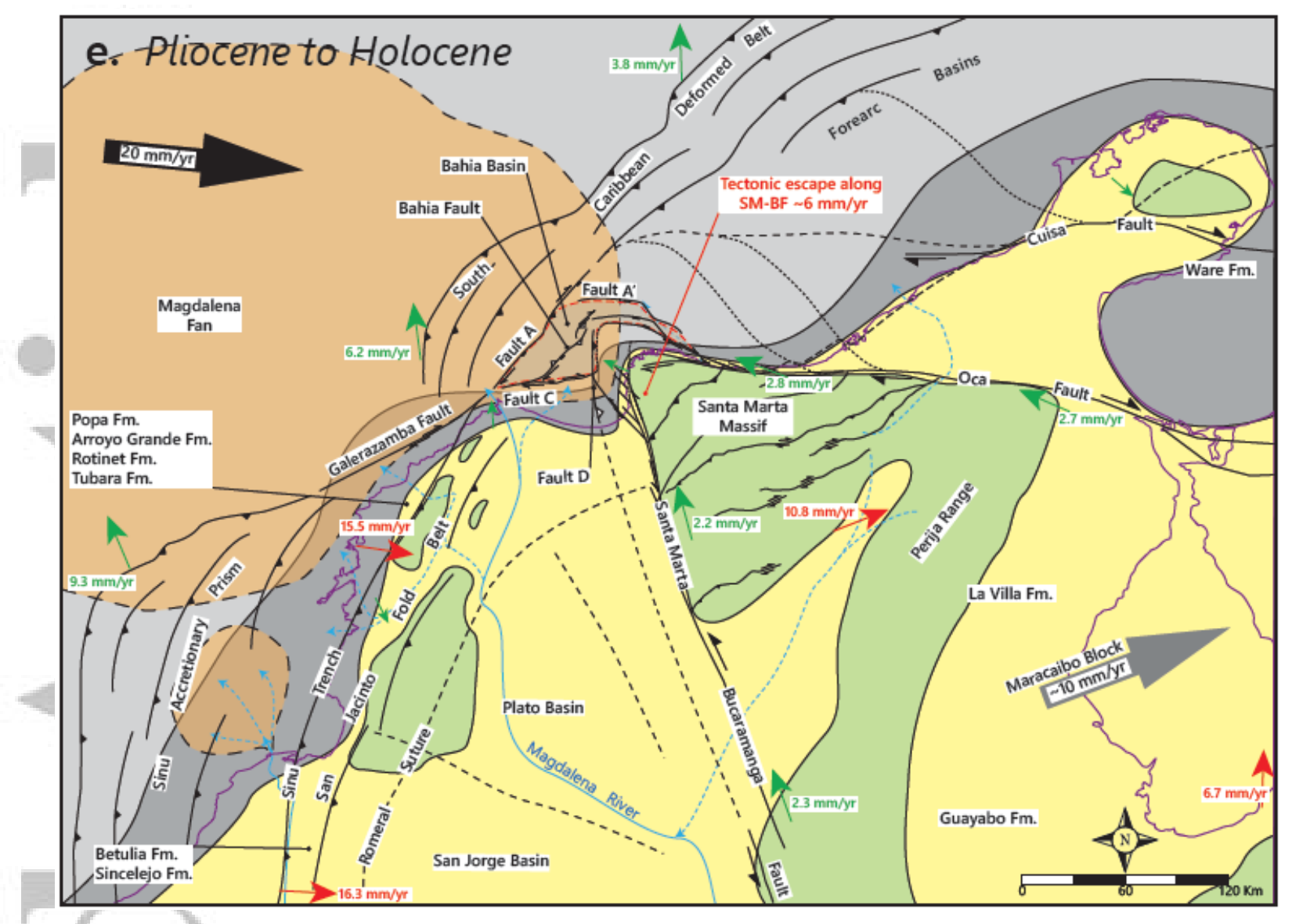

Figure 9. Schematic paleogeographic reconstruction. a.) At middle Eocene times, an early Paleogene magmatic arc dominates the NW corner of South America. The continuous orogen include parts of the current Central Cordillera, Santa Marta Massif, Guajira Peninsula and Leeward Antilles. b.) Late Eocene to Oligocene times. Right-lateral strike-slip deformation started in the NW corner of South America causing the opening of transtensional basins, and the displacement and dismemberment of the early Paleogene margin. c.) Early to middle Miocene times. Break-up and dispersion continued along strike-slip faults, together with the formation of transtensional basins. The Bahia Basin formed at the western end of the Oca Fault. d.) Late Miocene times. The Magdalena River started to drain northwards and deepwater turbidites were deposited in the gap created by the break-up and displacement of the accretionary prism. This displacement is also recorded by continuous right-lateral deformation in the Bahia Basin. e.) Pliocene to Holocene times. Continuous strike-slip deformation and the tectonic escape of the Maracaibo Block cause transpression and basin inversion along the Bahia Fault. Red arrows are from Trenkamp et al. (2002) and green arrows are from Symithe et al. (2015); arrows not to scale. 